\title{
社会基盤施設の維持・修繥工事における 専門工事企業の役割と制度設計
}

\author{
浜田 成一 ${ }^{1} \cdot$ 杉原 $_{\text {栄作 }}^{2} \cdot$ 貝戸 清之 $^{3} \cdot$ 水谷 大二郎 $^{4}$ \\ 1 正会員 大阪大学大学院工学研究科 地球総合工学専攻・HAMADA 建設マネジメント研究所 \\ ( ₹ 565-0871 吹田市山田丘 2-1) \\ E-mail: s-hamada@civil.eng.osaka-u.ac.jp \\ 2 正会員 玉石重機株式会社（ 厂 815-0081 福岡市南区那の川 1-12-12） \\ E-mail: ei-sugihara@tamaishi.co.jp \\ 3 正会員 大阪大学准教授 大学院工学研究科 地球総合工学専攻（† 565-0871 吹田市山田丘 2-1) \\ E-mail: kaito@ga.eng.osaka-u.ac.jp \\ 4 学生会員 大阪大学大学院工学研究科 地球総合工学専攻・日本学術振興会特別研究員 DC（ ₹ 565-0871 吹田市山田丘 2-1） \\ E-mail: d-mizutani@civil.eng.osaka-u.ac.jp
}

\begin{abstract}
建設業法上，建設企業は総合工事企業と専門工事企業に分類される。本研究では，老朽化が進む社会基盤施 設に対する維持・修繥工事の需要の増加と, 資本金階層別の建設企業の維持・修繥工事の受注件数や請負契約 金額に関して, 統計調査データの分析やヒアリング調査を実施し，一般的な維持・修繥工事の大半は，資本金 1,000 万円以上 5,000 万円未満の専門工事企業が受注していることを明らかにした．さらに，1）官公需法の下 では維持・修繥工事において専門工事企業が中心的な役割を担うこと，2）それにより維持・修繥工事の不完備 性を軽減し得ること，3）発注方式として, 設計・施工一括発注方式が望ましいことを述べた。一方で, 専門工 事企業には技術の専門性のみならず，維持・修繥工事全体を管理する総合技術力が要求されることに言及した.
\end{abstract}

Key Words : specialized constructor, maintenance and repair works, incompleteness, act on ensuring the receipt of orders from the government and other public agencies by SME

\section{1.はじめに}

社会基盤施設に関連する全ての工事は，新設工事と 維持・修繥工事に分類される. 新設工事は, 構造物およ び付属設備の新たな建設，もしくは増改築および改良 を対象する．また，災害を契機とする改良復旧工事お よび除去・解体工事も含む. 一方で, 維持・修繥工事は, 新設工事以外の工事を指し, 既存の構造物や付属設備 に対して従前の機能を保つために行う経常的な補修工 事，改装工事，移転工事，災害復旧工事および区画線 設置などを含む．新設工事と維持・修繒工事の両方を 含む工事については，主たる内容により適宜区分され る. 建設業法では, これらの業務に従事する建設業者 （以下，建設企業）は，下請負契約における注文者であ る元請負人（以下，元請負建設企業）と下請負契約に おける請負人である下請負人（以下，下請負建設企業） に分類される，なお，本研究における「維持・修繥工 事」は, 「維持・補修工事」などと称される場合も含み, 実施工のみならず, 工事契約, 発注者協議, 基本設計, 設計変更協議, 担保期間内の補償など, 建設企業が従 事する全ての業務を包括する.

維持・修繥工事は, 工事の対象となる社会基盤施設 の構造特性, 使用履歴や環境条件を踏まえた上で, 施
工者の経験とノウハウを活用した新設工事とは異なる 技術や技能が要求される. 例えば, 維持・修繥工事で は, 社会基盤施設の利用状況や重要性によって, 供用 状態下で工事を進める活線施工が求められることも少 なくない。このような状況や, 事故・災害時の復旧の迅 速性, さらには維持・修繥工事が大規模集約型の新設 工事と異なり，小規模分散型の事業であることを考慮 すると, 維持・修繥工事は, 地元に根ざし, かつ高い技 術や技能を有する専門工事企業（2.(1) で定義）のよう な中小企業が今後中心的な役割を担っていくことが期 待される. また, 社会基盤施設の維持・修繥工事のよ うな公共事業には, 景気浮揚を期待する政策的な側面 もある. 実際に，管理者側においても，維持・修繥工事 の発注に際しては「官公需についての中小企業者の受 注確保に関する法律」（以下，官公需法．詳細は付録 I を参照）の適用により, 中小の総合工事企業 (2.(1)で 定義）や専門工事企業への受注機会確保に務めている. 例えば，発注工事を細分化すると同時に，建設企業を 資本金によって階層化して，様々な企業が公平に受注 できる機会を増やしている，維持・修繕工事の将来的 な増加が見込まれる中で, 今後は地元の中小企業の中 でも特に優れた技術・技能を有する専門工事企業が実 施工のみならず工事全体の中核になることが期待され 
ている．しかし，専門工事企業の実態や役割，官公需 法の適用下における維持・修繥工事に対する制度設計 について言及した研究は著者等の知る限り存在しない.

以上のような問題意識のもと, 本研究では, 専門工 事企業に焦点を当て, 社会基盤施設の維持・修繥工事 における専門工事企業の役割とそれを支える制度設計 について考察する．具体的には，資本金階層別の建設 企業に対して，それらの企業の維持・修繥工事の受注 件数や請負契約金額に関して, 統計調査データの分析 に加え，ヒアリングによる実態調査を実施する。その 結果，1）官公需法の下では維持・修繥工事において専 門工事企業が中心的な役割を担うこと，2）それにより 維持・修繥工事の不完備性を軽減し得ること，3）発注 方式として, 設計・施工一括発注方式が望ましいこと を述べる．また，専門工事企業には技術の専門性のみ ならず，工事全体を管理する総合技術力が要求される ことを言及する. 以下，2. で本研究の基本的な考え方 を述べ，3. で公共工事が新設工事から維持・修繥工事 へ移行している現状を整理する．4. で建設企業の公共 工事受注実態の調査と分析を行い，資本金階層別建設 企業の維持・修繥工事の受注件数や請負契約金額につ いて調査する．5. で官公需法のもとで維持・修繥工事 を効率的に実施するためには設計・施工一括発注方式 が望ましいことを述べる.

\section{2. 本研究の基本的な考え方}

\section{(1) 総合工事企業と専門工事企業}

建設業は労働集約型産業であり, 少数の大手建設企 業を頂点に，下請負建設企業が階層的に連なる構造を 有している，建設業を営むには，建設業法の規定に合 致した要件を備えて国土交通大臣や知事の許可を得る 必要がある。ただし, 軽微な建設工事（建築一式工事 以外の建設工事において，工事 1 件の請負契約金額が 500 万未満の工事) のみを請け負って営業する場合に は，必ずしも建設業の許可を受けなくてもよい. 建設 業の許可を得た業者（以下，許可業者）の工事種類は, 表-1に示すように, 土木一式, 建築一式から大工・左 官などを含めて 28 種類にも及び，個々の工事種類に対 応する工事業種が存在し, それらの業種ごとに建設業 許可を取得する必要がある 1$)$. さらに，建設業許可に は, 上記の工事の種類による分類に加え, 複数の県に 営業所を設置するか否かによる分類（複数の都道府県 の場合は国土交通大臣許可，1つの場合は知事許可）が ある 1).

本研究では, 表-1に示す 28 種類の工事あるいは業種 を日本標準産業分類 ${ }^{2)}$ に従い分類する. 表-1 内で日本 標準産業分類の「大分類 D-建設業」内の「中分類 $06-$
表-1 建設業法での許可業者の工事種類および業種一覧 ${ }^{1)}$ と 本研究における企業区分

\begin{tabular}{|c|c|c|c|}
\hline 企業区分 & 番号 & 建設工事の種類 & 建設業の業種 \\
\hline \multirow{7}{*}{ 総合工事企業 } & 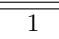 & " 土木一式工事 & " 土木工事業 \\
\hline & 2 & 建築一式工事 & 建築工事業 \\
\hline & 3 & 舗装工事 & 舗装工事業 \\
\hline & 4 & 浚渫工事 & 浚渫工事業 \\
\hline & 5 & 造園工事 & 造園工事業 \\
\hline & 6 & 水道施設工事 & 水道施設工事業 \\
\hline & 7 & 清掃施設工事 & 清掃施設工事業 \\
\hline \multirow{21}{*}{ 専門工事企業 } & 1 & 大工工事 & 大工工事業 \\
\hline & 2 & 左官工事 & 左官工事業 \\
\hline & 3 & $\begin{array}{c}\text { とび・土工・ } \\
\text { コンクリート工事 }\end{array}$ & $\begin{array}{c}\text { とび・土工 } \\
\text { コンクリート工事業 }\end{array}$ \\
\hline & 4 & 石工事 & 石工事業 \\
\hline & 5 & 屋根工事 & 屋根工事業 \\
\hline & $6^{*}$ & 電気工事 & 電気工事業 \\
\hline & $7^{*}$ & 管工事 & 管工事業 \\
\hline & 8 & $\begin{array}{c}\text { タイル・れんが・ } \\
\text { ブロック工事 }\end{array}$ & $\begin{array}{l}\text { タイル・れんが・ } \\
\text { ブロック工事業 }\end{array}$ \\
\hline & 9 & 鋼構造物工事 & 鋼構造物工事業 \\
\hline & 10 & 鉄筋工事 & 鉄筋工事業 \\
\hline & 11 & 板金工事 & 板金工事業 \\
\hline & 12 & ガラス工事 & ガラス工事業 \\
\hline & 13 & 塗装工事 & 塗装工事業 \\
\hline & 14 & 防水工事 & 防水工事業 \\
\hline & 15 & 内装任上工事 & 内装仕上工事業 \\
\hline & $16^{*}$ & $\begin{array}{l}\text { 機械器具 } \\
\text { 設置工事 }\end{array}$ & $\begin{array}{c}\text { 機械器具 } \\
\text { 設置工事業 }\end{array}$ \\
\hline & $17^{*}$ & 熱絶縁工事 & 熱絶縁工事業 \\
\hline & $18^{*}$ & 電気通信工事 & 電気通信工事業 \\
\hline & $19^{*}$ & さく井工事 & さく井工事業 \\
\hline & 20 & 建具工事 & 建具工事業 \\
\hline & $21^{*}$ & 消防施設工事 & 消防施設工事業 \\
\hline
\end{tabular}

総合工事業」に分類される 7 種類の建設工事のいずれか の建設業許可を持つ（当該種類の建設工事を主要な業 務とする）企業を本研究では総合工事企業と定義する. また，日本標準産業分類の「中分類 06-総合工事業」に 「主として土木施設, 建築物を完成することを発注者に 対し直接請負う事業所又は自己建設で行う事業所」と 記されているように, 元請負建設企業の大部分は総合 工事企業である（ただし, 本研究で対象とするような専 門工事企業が元請負建設企業と, あるいは, 総合工事 企業が下請負建設企業となるような場合も存在し, そ のような場合には, 適宜, 柔軟に元請負建設企業, 下 請負建設企業を定義する必要がある点には留意された い). そのため, 以下では断りのない限り, 元請負建設 企業は総合工事企業と同じ意味で使用するものとする. 総合工事企業は，発注者から直接工事を請け負い，そ の建設工事の一部に対して，専門工事企業と下請負契 約を締結することにより，専門工事企業に下請負発注 することができる。その際, 総合工事企業には, 特定 建設業の許可を受けた企業（発注者から直接工事を請 け負い，かつ 3,000 万円（建築一式工事の場合は 4,500 万円）以上の工事を下請負建設企業に発注できる企業） として厳しい要件が課されている。一方, 日本標準産 業分類において,「中分類 07-職別工事業（設備工事業 を除く)」,「中分類 08-設備工事業」に該当する建設業 許可のいずれかを持つ（当該種類の建設工事を主要な 
業務とする）企業を本研究では表-1に示すように専門 工事企業と定義する．下請負建設企業の大部分は専門 工事企業であり，以下では，下請負建設企業は専門工 事企業と同じ意味で使用する（なお，日本標準産業分 類において,「中分類 07-職別工事業（設備工事業を除 く)」は「主として下請として工事現場において建築物 又は土木施設などの工事目的物の一部を構成するため の建設工事を行う事業所」と定義されているが, 「中分 類 08-設備工事業」は「設備を完成することを発注者に 対し直接請負う事業所又は自己建設を行う事業所並び に下請としてこれらの設備の一部を構成するための設 備工事を行う事業所」と定義されており,「中分類 08 -設 備工事業」に該当する建設企業は元請負建設企業にな る場合もある点には留意されたい)。専門工事企業は, 総合工事企業の下請負として, 例えば土工事や躯体工 事の一部を請け負うことになるが，それらの大半が中 小・個人企業で構成されている。一般的に，下請負契約 においては，表-1に列挙した 28 種類の工事ごとに，該 当する建設工事の建設業許可を受けた専門工事企業が 総合工事企業と契約を結ぶことになる。なお, 総合工 事企業から直接工事を請け負った 1 次の下請負建設企 業（専門工事企業）から，さらに工事を請け負う 2 次, 3 次の下請負建設企業（これらも専門工事企業であり, 再下請負建設企業とも称する）も存在する. 以上のよ うに，国内の建設産業は，総合工事企業を頂点とする 細分化された技能職種による分業体制が敷かれている. 一般的に専門工事企業に関しては，明確な定義は見当 たらないため, 本研究においては以上の考え方を採用 することとする. ただし, 建設企業の中には本研究で 定義する総合工事企業と専門工事企業の双方の建設業 許可を同時に保有している企業も少なくない.このよ うな建設企業において適切な建設契約形態を本研究の ように議論する際には，1）上記で「(当該種類の建設 工事を主要な業務とする)」と記したように各建設会社 の主要な業務に着目する，2）3.で詳述するように建設 企業の資本金に着目する，3）対象とする建設工事の規 模・種類を与件とした場合には当該工事において各建 設企業が期待される役割などを考慮する，というよう に，それぞれのケースに応じて，柔軟に総合工事企業 と専門工事企業を定義する必要がある。 また, 本研究 では公共工事のうち，土木工事に着目する。

\section{（2）建設業法の改正と専門工事企業}

建設業法は, 1949 年 5 月に衆・参両院で可決された。 その後, 幾多の改編を経て, 建設業は 1971 年 4 月に登 録制度から許可制度へ移行した。登録制度から許可制 度への移行は, 1965 年以降に建設投資の需要が増大す る中で, 施工能力, 資力, 信用に欠ける業者の参入が
後を絶たないことを契機に，不良・不適格業者の排除 を目的として進められた. その後, 建設企業の合理化, 近代化が求められ, 1987 年に指定建設業が法制化され, 監理技術者制度の整備が行われた。また，1990 年代お よび 2000 年代初頭にかけて公共事業の入札を巡って建 設企業の談合が問題となり, 司法による摘発やマスコ ミ等の非難を受け, 建設産業は国民からの信用を失う ことになった。このような公共工事の一連の不祥事が 惹起され, 不良・不適格業者の徹底排除, 公共工事の 適正施工の確保, 建設業許可申請のための事務処理の 簡素化などを目的として, 適宜法改正が行われてきた。 このような経緯の中で, 協調の原理を基盤としてきた 建設産業にも競争の原理が導入された。競争の原理の 導入は, 建設産業の透明性や公平性の向上に貢献した が，その一方で低価格入札が多く発生する事態となっ た。入札価格低下によって経済効率性が改善されるな らば，それは社会全体にとって歓迎すべきであるが，過 度な低価格入札は総合工事企業から業務を請け負う専 門工事企業の経営状況を悪化させる側面も有する.

現在, 土木一式工事や建築一式工事以外の一般建設 業許可（表-1）は 28 種あり, 個々に具体的な建設工事 および建設業の種類が明示されている. 建設工事のう ち，土木工事を例にあげると，公共工事を請け負った 総合工事企業は, 工事を完成させるために大工, 鉄筋, とび・土工・コンクリート工事から, 防水工事, 電気工 事, 塗装工事, 舗装工事まで多岐にわたる工事をそれぞ れの専門工事企業に発注して下請負契約に従い, 工事 を完成させていく.このように, 建設プロジェクトは, 発注者と工事請負契約を直接交わし, その工事の完成 まで総合的に企画・調整を行う総合工事企業と, その管 理のもとに下請負を担当する専門工事企業によって遂 行される. この場合, 立場的に弱者となるのは, 総合工 事企業に対して従属的関係にある専門工事企業である. 現状のように低価格入札, すなわち価格競争だけが先 行している建設市場では, その傾向がますます助長さ れることは想像に難くない, また, 近年では, 総合工 事企業からの専門工事企業に対する支払い関係は, 現 金支払いが少なくなり, 手形による支払いが大幅に増 加している. さらに, 基準日から 120 日後でないと全 額弁済されない手形も一般的となってきている ${ }^{4)}$. 国 土交通省の通知 ${ }^{5)} に よ り$, 最近では改善傾向がみられ るが, 手形の弁済期間に起因した収支バランスの不良 による資金繰りの悪化が深刻化し, 設備投資や保有に 支障を来す企業も少なくない.

\section{(3) 新設工事から維持・修繥工事への移行}

国土交通省では, 社会基盤施設に対する将来的な維 持・修繥費用を推計し，2011 年から 2060 年までの 50 


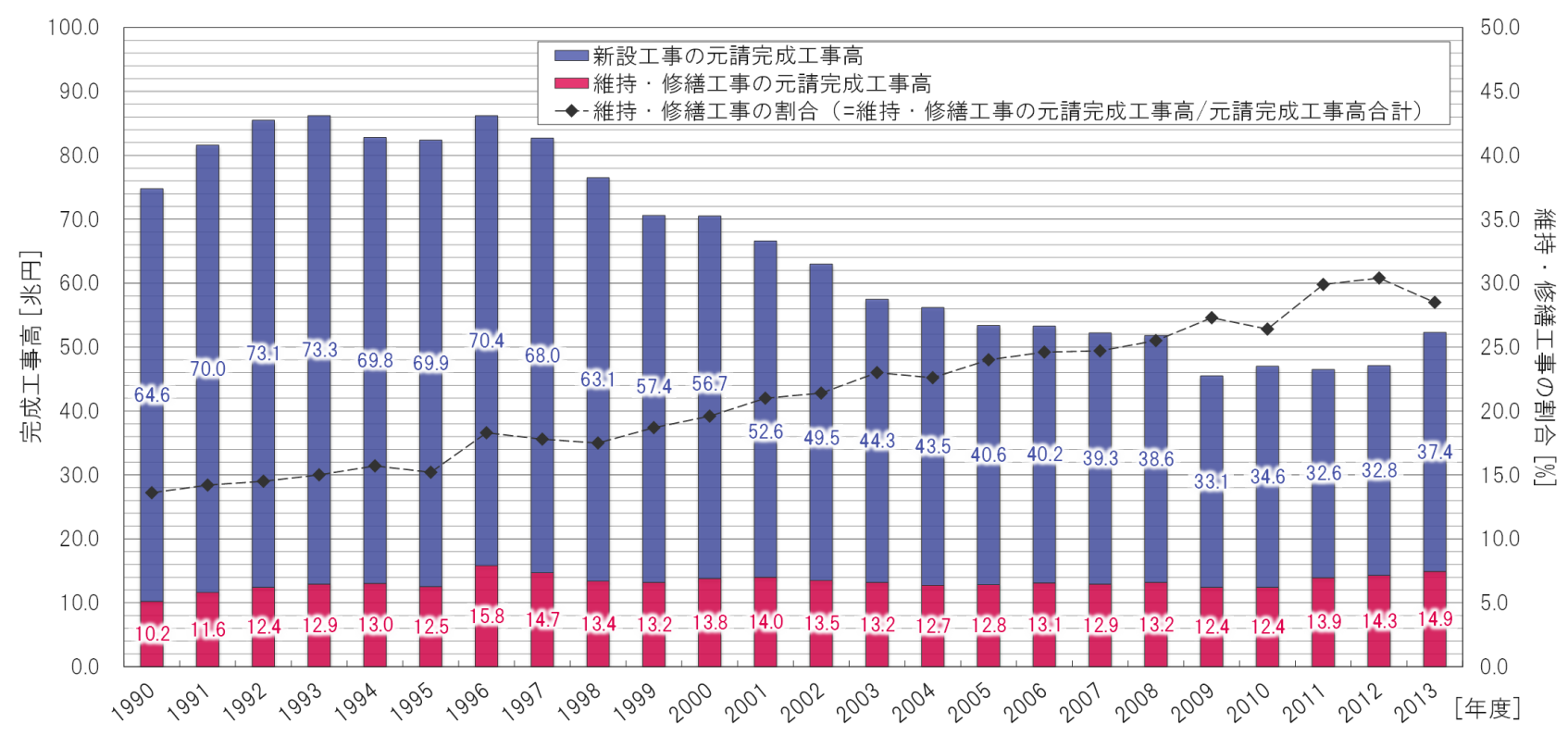

注）参考文献 7$), 8 ＼mathrm{~ を 用 い て 著 者 等 か ゙ 作 成 し た . ~}$

図-1 元請負完成工事高および維持・修緓工事割合の推移

年間で 190 兆円の更新費用が必要になるという試算結 果を公表している ${ }^{6)}$ 。一方で, 実績值として，1990 年 から 2013 年に亘る新設工事と維持・修繥工事それぞれ の完成工事高の推移 7),8) を図-1に示す. 図中の青色が 新設工事, 赤色が維持・修繥工事であるが，これらは いずれも元請負完成工事高であることに留意されたい （同図はあくまでも元請負建設企業，一般的には総合工 事企業に着目した完成工事高である. 本研究で着目す る専門工事企業が元請負として受注する場合もあるが, 総合工事企業の完成工事高と比較するとその值は極め て少ない)。また，同図には元請負完成工事高の合計に 占める維持・修繥工事の元請負完成工事高の割合（黒色 破線）も併せて示している. 国内の建設投資額は 1996 年の 82.8 兆円をピークに減少し続け, 2013 年度は 50.0 兆円（うち，政府による建設投資額は約 22.0 兆円）と なる見通しである ${ }^{9)}$. 特に新設工事に関する元請負完 成工事高にその傾向が顕著に表れている，一方で図-1 より, 維持・修繥工事に関する元請負完成工事高につい ては, 1996 年度に 16 兆円に達した後, 新設工事に関す る元請負完成工事高が低下する中にあっても，13 兆円 から 14 兆円でほぼ一定を保っている. 新設工事が落ち 込んでいる分, 新設工事に関する元請負完成工事高に 占める維持・修繥工事に関する元請負完成工事高の割 合は 1990 年度が $14 \%, 1998$ 年度が $18 \%, 2008$ 年度が $26 \%, 2011$ 年度が $30 \%$ と相対的に増加していることが わかる7).

\section{（4）官公需法}

国土交通省は建設市場の縮小で経営が悪化する中小 の建設企業対策として, 維持・修繥工事への進出を, 官 公需法に基づく通達を出すことにより支援している. 官 公需法は, 中小企業が国内経済の活性化および強化に 重要な役割を担っていることに鑑み, 国等の調達にお いて中小企業の受注機会の増大を図ることを目的とし ている ${ }^{10)}$ 。官公需法は, 国などが発注する公共工事が 中小企業に優先的に調達される法的根拠となっている. 地方自治体に関しても，国の施策に準じて施策を講じ るように努めなければならないとしていることから，地 方自治体においても官公需法は地元の中小企業優遇策 として機能している ${ }^{10)}$.

実際に, 後述するように公共工事の完成工事高に占 める維持・修繥完成工事高の割合が中小建設企業ほど 高くなっている. 2008 年度の完成工事高に占める新設 工事と維持・修繥工事の完成工事高の割合をみると, 完 成工事高 500 億円以上の建設企業の維持・修䋨完成工 事高が全体の $15 \%$ であるのに比べ，完成工事高 1 億円 未満の建設企業の維持・修繥完成工事高は $49 \%$ と相対 的に高い. 本研究ではこのような実態を踏まえ, 今後 の維持・修繥工事における専門工事企業の役割と, そ の役割を果たすための制度設計について考察を行う。

\section{（5）新設工事と維持・修繯工事の不完備性の相違}

建設工事の請負契約は, 地質条件, 自然条件, 設計 変更, 工事範囲の変更, 法律の改廃など, 建設プロジェ 


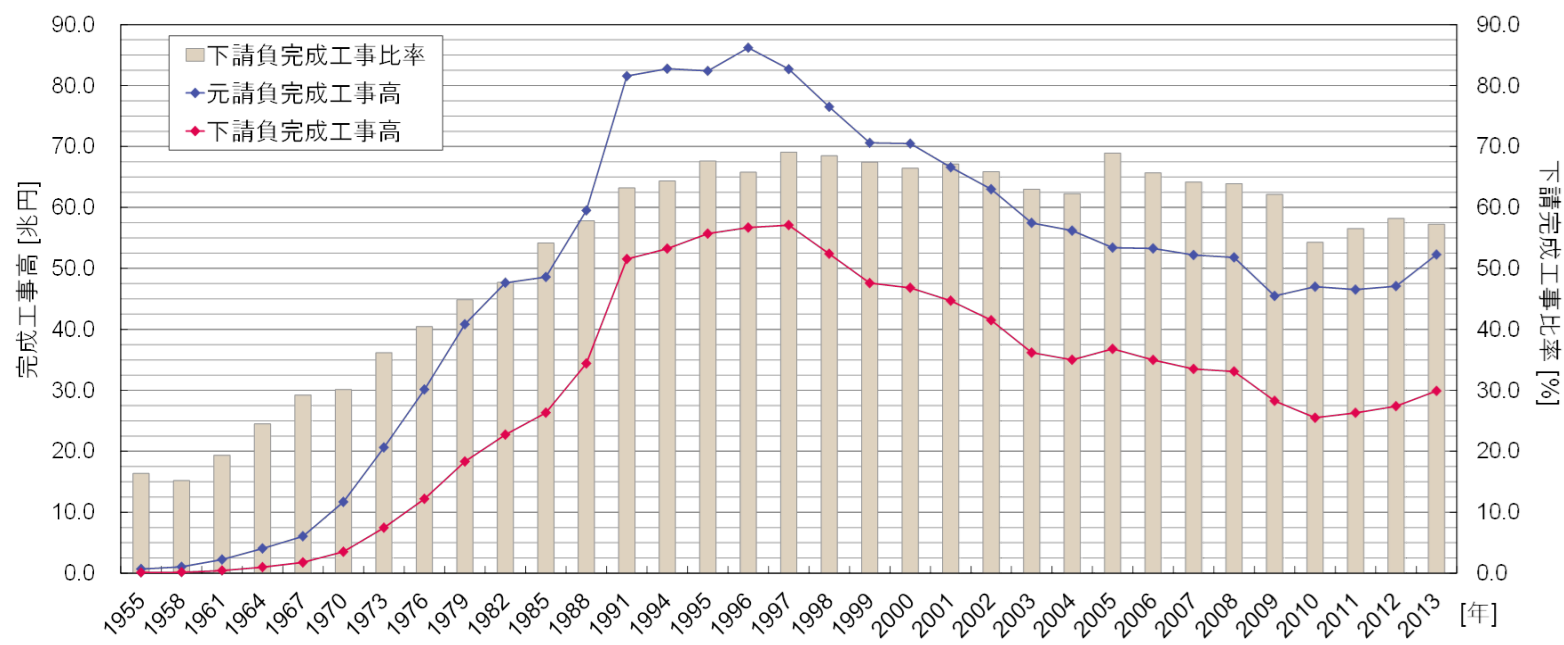

注）参考文献 7$), 16)$ の数值を用いて著者等が作成した。1955 年〜1974 年までは暦年調査であり，1975 年以降 は年度調査である. 下請負完成工事比率は, 下請負完成工事高を元請負完成工事高で除した割合を示す.

図-2 下請負完成工事比率の推移

クトの執行過程において，契約締結時に発注者，受注 者の双方が予見できなかった事柄が発生する可能性を 含んでいる ${ }^{11), 12)}$ 。このような多様な不確実性が存在 するために，請負契約に全ての状況を網羅することは 不可能であることから，建設工事の請負契約は一般的 に不完備契約 13),14) と位置づけられている.すなわち， 不完備契約においては, 請負契約の中に全ての事柄を 記載できない特性を持っており，建設プロジェクトの 執行過程で, 各事象に応じた設計変更を実施すること を基本としている.

新設工事と維持・修繥工事では, 委託設計や建設工事 の請負契約の不完備性に差異がある．新設工事は，地 質, 自然条件等の不確実要因が大きく影響するために, 設計図書において全てを予見できない場合が多く，そ の結果大幅な設計変更となる場合も少なくない。一方 で，維持・修繥工事を実施する段階では，竣工図書（竣 工図, 施工計画, 数量内訳書, 実施工程表, 打合せ簿, 指示簿等) や竣工後の管理記録等の書類が保存されて いる場合が多い，すなわち，新設工事の際には不完備 であった事項が維持・修繥工事の際には完備情報となっ ている. また，正式な記録として残っていなくとも，新 設工事の際に実施工に係わっていた建設企業（竣工図 書に記載されていないような施工の詳細を把握してい る建設企業）であれば，対象となる社会基盤施設の損 傷や劣化が設計的要因, 施工的要因, あるいは地域的 要因によるものかの判断がある程度は可能である. さ らには当該施設の被災履歴を把握していることも多い. 維持・修繥工事に関しては, このように対象となる社 会基盤施設を熟知している企業が関与することにより 施工の品質が向上すると考えられる。

\section{3. 統計調査データを用いた実態把握}

\section{（1）工事実績と経営状況}

専門工事企業は，1959 年まで归建設省の管理・監督 による直轄施工体制のもとで, 総合工事企業への労務 提供を行ってきた。その後, 旧建設省の管理・監督か ら, 総合工事企業の管理・監督による直接施工体制に 移行するに伴って，専門工事企業は総合工事企業の管 理のもとで業種別に分けられた工種を請け負うように なった ${ }^{15)}$. 高度経済成長期に入り, 建設投資が拡大す る中で, 東京オリンピックや高速道路建設などの建設 プロジェクトが始まり，施工に必要な設備投資も飛躍 的に増加していった。そのために, 総合工事企業による 直接施工体制のもと，専門工事企業自身も工事に直接 使用する建設機械や建設仮設資材に対する投資を大幅 に拡充させた。その結果，建設投資に占める下請負完 成工事高，下請負完成工事比率はともに増加した。そ の後も継続的に建設投資が拡大する中で，下請負契約 を基本とする総合工事企業（元請負建設企業）と専門 工事企業（下請負建設企業）の施工体制は, 請け負った 工事を履行するために再下請負建設企業（専門工事企 業）に業務の一部を請負わせるなど，現在の階層的な 下請負構造を有する施工体制につながっていった。そ の結果, 再下請負も含む下請負完成工事比率は一層高 まった.

国土交通省の建設工事施工統計調査報告では，建設 業の労㗢生産性に関する調査の一環として, 発注者か ら直接請け負った工事の出来高相当額である元請負完 成工事高と, 元請負建設企業から請け負った工事の出来 高相当額である下請負完成工事高を調査している. 下 


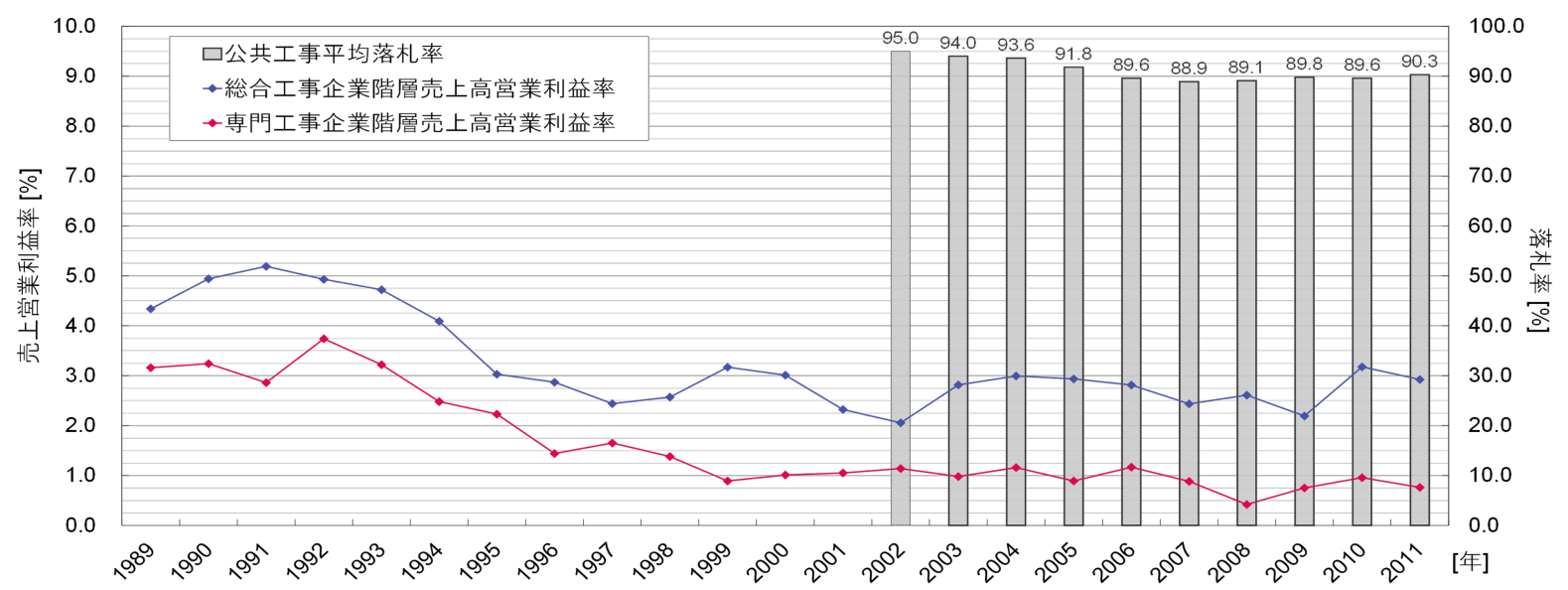

注）参考文献 7),16) の数值を用いて著者等が作成した.

図-3 階層別売上高営業利益率と平均落札率の推移

請負完成工事比率は, 調査対象の全ての建設企業につ いて，元請負として請け負った工事金額に対する，下 請負として請け負った工事金額の平均的な比率を表し ている。ただし，下請負完成工事高については，建設 業が階層的な下請負構造を有するために数值的な重複 があると考えられるが，建設業の労働生産性の全体傾 向をつかむ程度の信頼性は確保できていると判断した。

図-2 には，元請負完成工事高，下請負完成工事高と ともに下請負完成工事比率 (=下請負完成工事高/元 請負完成工事高, 図中の棒グラフ）の推移を示す. 1960 年代において下請負完成工事比率は $19 \%$ ２9\%であっ たが，1980 年代後半から 2009 年度にかけて $70 \%$ 近く にまで上昇していることが見て取れる，下請負完成工 事比率が高まった要因は, 元請負建設企業の業務内容が 実施工から工事の管理・監督へシフトする中で, 実施工 に関して下請負建設企業への依存が高まったことにあ ると考えられる.ささら，1 次下請負の専門工事企業の 中には, さらに 2 次, 3 次下請負の専門工事企業への再 下請負を選択する企業も存在した。このような下請負 契約によって大幅に増加した公共工事を消化してきた が，中には請け負った大部分を再下請負建設企業に発 注し自らは工事管理だけを行う専門工事企業も現れた。 多種多様な下請負契約や施工体制によって専門工事企 業の下請負完成工事比率はさらに上昇して 1997 年度に は $69 \%$ に達した。その後, 1997 年度から 2009 年度ま では, 元請負完成工事高（図中の青実線）の減少の影 響を受けたものの, 下請負完成工事比率は比較的緩や かな減少にとどまった。下請負完成工事比率は，2010 年度には $54 \%$ まで低下したが, その後やや上昇に転じ て 2013 年度には $57 \%$ まで回復している.

図-3 は，代表的な資本金階層に属する 2 つの建設企
業を選び, その売上高営業利益率と平均落札率の推移 から, 建設企業の本業業務からの収益性の傾向を分析 したものである.1つ目の資本金階層を総合工事企業階 層として位置付け, 総合工事企業階層には元請負工事 を主体とする（資本金階層区分は建設工事施工統計調 査 ${ }^{6)}$ に従い, 平成 25 年度の同調査で土木分野での元請 負完成工事高が最も多い階層である）資本金 10 億円以 上の企業を選定した。同階層の総合工事企業は, 企業 数としては全体の $0.1 \%$ 程度に過ぎないが, 完成工事高 総額の 30〜 40\%を占める. 2 つ目の資本金階層として は, 下請負工事を主体とする (平成 25 年度の建設工事 施工統計調査で土木分野での下請負完成工事高が 1 番 目, 2 番目に多い階層を合わせて）資本金 1,000 万円以 上 5,000 万円未満の企業を専門工事企業階層として選定 した. 該当する専門工事企業は, 企業数としては全体の $40 \%$ 以上を占め, 完成工事高総額においても約 $35 \%$ を 占める. 同図中の売上高営業利益率とは, 営業利益を 売上高で除して 100 を乗じた利益率であり, 本業の収 益性に関する評価指標に用いられる。総合工事企業階 層, 専門工事企業階層の売上高営業利益率は 1991 年か ら 1992 年度に最大となり, その後は下降傾向にある. 建設産業は, 2001 年以降, 「公共工事の品質確保の促進 に関する法律」，「官製談合防止法」の制定や「公共工 事の入札及び契約の適正化の促進に関する法律」の強 化などの様々な法改正等が行われ, 透明性が高く公正 な競争原理を基盤とした入札制度を構築してきた。ま た, 日本土木工業協会は, 2005 年 12 月に日本建設業団 体連合会および建築業協会とともに会長名で会員会社 に対して,「公正な企業活動の推進について」を通知し, コンプライアンスの徹底を要請した。 また, 新しいビ ジネスモデルを構築することを決意し， 2006 年 4 月に 
「透明性ある入札・契約制度に向けて 改革姿勢と提言」 を発表した ${ }^{17)}$ 。これらの施行により建設産業は, 競争 原理に基づいた受注競争へと移行していった ${ }^{18)}$. 建設 産業にとっては厳しい制約下におかれる状況であった が，総合工事企業階層の売上高営業利益率（図中の青 実線）は，平均落札率（図中のヒストグラム）の $5 \%$ 以 上の急激な下降にもかかわらず，2002 年以後に緩やか ではあるが，上昇傾向が続いている．しかしそれとは 対照的に専門工事企業階層の売上高営業利益率（図中 の赤実線）は，定常的な停滞・下降傾向にあり，2008 年以降は $1.0 \%$ 以下にまで落ち込んでいる. 2 者の売上 高営業利益率を比較してみると, バブル期から 1997 年 頃の差に比べて，それ以後は明らかに 2 階層間の売上 高営業利益率の差が大きくなっている. 主たる要因と して, 元請負である総合工事企業は，1）内部統制の推 進，2）受注希望工事の選択，3）下請負である中小の専 門工事企業に対するコストダウン要請，4）建設資材の 集中購買など, 経営効率を高めるための複数の選択肢 を保有していることがあげられる．特に, 総合工事企 業階層と専門工事企業階層の関係に着目すれば，総合 工事企業が専門工事企業を選択するときに，施工能力 ではなく，低価格を優先させる傾向が強くなっている. このことは, 国土交通省が 2005 年から 2006 年にかけ て完成した 270 の建設工事（公共工事 141 工事，民間 工事 129 工事）を対象に，その工事に下請として携わっ た専門工事業者 536 社に対し，アンケート調査した結 果からも明らかとなっている ${ }^{19)}$ 。一方で, 専門工事企 業には, 総合工事企業のような経営上の選択肢はない。 総合工事企業からのコストダウン要請によって発生す る経営的負担を減少させるために, 再下請負建設企業 に業務を順次先送りさせることにより営業利益を確保 している傾向がある。このような下請構造の重層化傾 向については, 2011 年の国土交通省建設産業戦略会議 の「建設産業の再生と発展のための方策 2011」20)にお いても取り上げられている.

\section{（2）資本金階層別の受注実態}

図-4～図-7 は，8 区分の資本金階層別に，社会基盤 施設の新設工事と維持・修繥工事の 2011 年度における 受注件数および請負契約金額を比較したものである. 新 設工事の受注件数は 97,168 件, 請負契約金額は 7 兆 140 億円であるのに対して, 維持・修緟工事の受注件数は 36,262 件，請負契約金額は 1 兆 10 億円であった 7 ). 資 本金階層別に比較してみると, 図-4 の新設工事の受注 件数に関しては，資本金 1,000 万円以上 1 億円未満の 建設企業で約 $77 \%$ を占め, 特に資本金 1,000 万円以上 3,000 万円未満の建設企業の受注件数が約 $41 \%$ を占めて いる. 一方, 資本金が 1 億円以上の建設企業は受注件

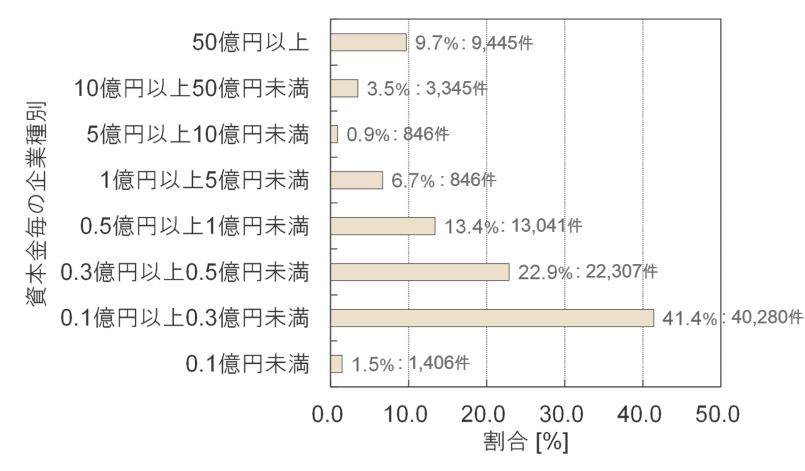

図-4 新設工事の受注件数割合

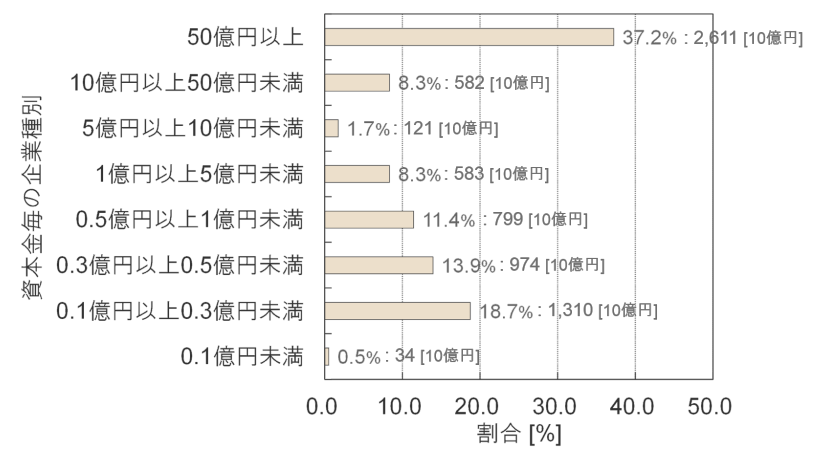

図-5 新設工事の請負契約金額割合

数そのものは低く，階層別では資本金 50 億円以上の企 業の $9.7 \%$ が最も高い. 図-5 の新設工事の請負契約金 額は，資本金 1,000 万円以上 1 億円未満の建設企業で 約 $44 \%$ 占めている．そのうち，資本金 1,000 万以上 3,000 万円未満の建設企業の請負契約金額は約 $19 \%$ であ る.一方で，資本金 50 億円以上の建設企業は約 $37 \%$ で, 他の階層の建設企業に比べて非常に高い請負契約金額 を受注している．新設工事の傾向としては，資本金 50 億以上の建設企業が他の階層の建設企業に比べて受注 件数は約 10\%と少ないものの, 請負契約金額は全体の 約 37\%（受注件数 9,445 件, 総請負契約金額 2 兆 6,110 億円）を占める。このとき，1件あたりの請負契約金額 は平均で約 2 億 7,600 万円となり, 資本金 50 億円以上 の建設企業が大規模な新設工事を請け負っている.

図-6 の維持·修繥工事の受注件数の傾向としては, 資 本金 1,000 万円以上 1 億円未満の建設企業で約 $80 \%$ を 占めている. 特に資本金 1,000 万円以上 3,000 万円未 満の建設企業の受注件数は約 $41 \%$ に達している。一方, 資本金 50 億以上の建設企業の受注件数は約 $6 \%$ と低い. 全体的な傾向は新設工事の受注件数（図-4）と同様で あるといえる. 図-7 の維持・修繥工事の請負契約金額 については，資本金 1,000 万円以上 1 億円未満の建設企 業で約 $66 \%$ を占め，なかでも資本金 1,000 万以上 3,000 万円未満の建設企業は約 $27 \%$ に達している. 資本金 5 億円以上の建設企業の割合は相対的に低く, 最も高い 


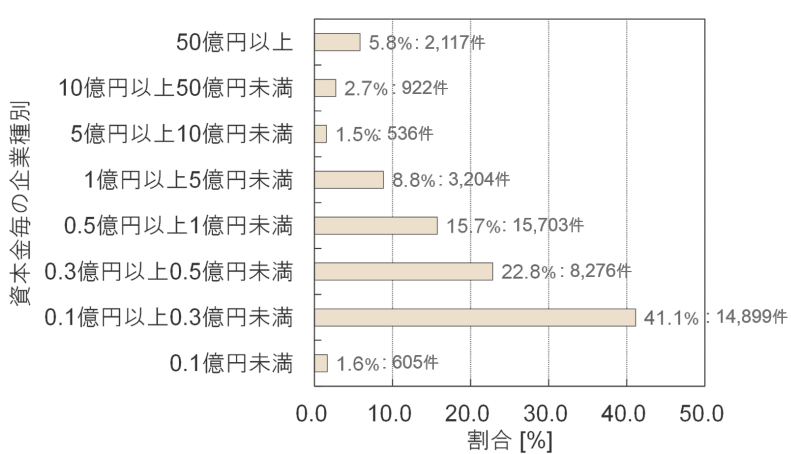

図-6 維持・修繥工事の受注件数割合

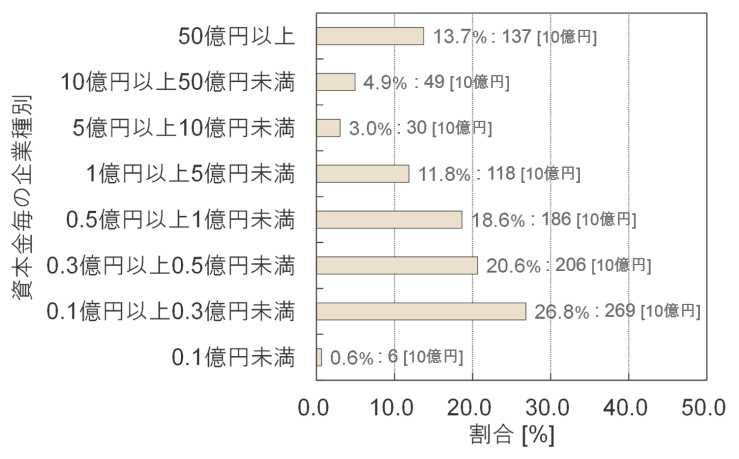

図-7 維持・修繥工事の請負契約金額割合

資本金 50 億以上の建設企業で約 $14 \%$ であり，10 億円 以上 50 億円未満の建設企業は約 $5 \%$ であ. 上述した ように受注件数に関しては新設工事と維持・修繥工事 で同様の傾向を示したが，図-5 と図 -7 の比較より，請 負契約金額の傾向は新設工事と維持・修繥工事で全く 異なることがわかる．維持・修繥工事の 1 件あたりの 請負契約金額（総請負契約金額 1,370 億円，総受注件 数 2,117 件）は平均すると 6,470 万円である. 維持・修 繕工事の特色は, 受注件数, 請負契約金額ともに資本 金 1,000 万円以上 1 億円未満の建設企業が中心になって おり，特に中心的な役割を果たす建設企業は，資本金 1,000 万円以上 3,000 万円未満であることがわかる. 述 べるまでもなく，本研究で着目する専門工事企業のほ とんどはこの階層に位置する。このような結果は，ラ ンク制 ${ }^{21)}$ の状況下では当然のこととも考え得る. 本研 究では, 資本金階層毎の請負契約金額の差異がランク 制に起因し生じたか自由競争のもとで生じたかは議論 の対象としない．また，5.で提案する発注方式はラン ク制のもとでも適用可能であると考えられ，本研究で の主張は共同企業体を用いることにより専門工事企業 において異なるランクの工事の受注機会を増やすといっ た目的ではないことには予め留意されたい.

なお，以上の結果は総請負契約金額と総受注件数に 対して, 資本金階層別の建設企業が占める割合をマク ロに整理したものである. 総請負契約金額や総受注件
表-2 公共機関発注工事 1 件あたりの請負契約金額

\begin{tabular}{c||c|c}
\hline 年度 & $\begin{array}{c}\text { 新設工事 } \\
\text { (万円/件) }\end{array}$ & $\begin{array}{c}\text { 維持・修繥工事 } \\
\text { (万円/件) }\end{array}$ \\
\hline \hline 2008 & 6,990 & 2,886 \\
\hline 2009 & 6,751 & 2,950 \\
\hline 2010 & 6,651 & 2,554 \\
\hline 2011 & 7,219 & 2,763 \\
\hline 2012 & 7,947 & 3,083 \\
\hline 2013 & 8,074 & 3,258 \\
\hline \hline 平均值 & 7,272 & 2,734 \\
\hline
\end{tabular}

表-3 都道府県発注工事における県内建設企業の受注割合

\begin{tabular}{c|c|c}
\hline & 県外建設企業による受注 & 県内建設企業による受注 \\
\hline \hline 受注件数 & 7,492 件（6.0\%） & $117,325$ 件（94.0\% $)$ \\
\hline 請負契約金額 & 11,394 億円（15.1\%） & 26,116 億円（84.9\%） \\
\hline 平均請負契約金額 & 15,200 万円/件 & 2,230 万円/件 \\
\hline \multicolumn{2}{|c}{$※ 2009$ 年度の数字. 括弧内は占有率. }
\end{tabular}

数が多くとも, 当該階層に属する建設企業数がそもそ も多い可能性がある。 そこで, 特定の建設企業 1 社が 受注した工事の受注件数と請負契約金額については 4. でヒアリング調査を実施する.

\section{(3) 維持・修繥工事の担い手}

表-2 に示すように, 2008 年度から 2013 年度の 6 年 間の請負契約金額の全国平均（公共機関発注分）は, 新 設工事で 1 件当たり約 7,300 万円, 維持・修繥工事で 約 2,900 万円であった 7). また, 表-3 には, 2009 年度 の都道府県発注工事に対する県内外の建設企業の受注 実態を整理している. 受注件数で比較すると, 県外建 設企業の割合は約 $6 \%$ に過ぎないが，請負契約金額は約 $15 \%$ を占めている. 平均の請負契約金額は, 県外建設企 業が 1 件当たり約 1 億 5,000 万円で，県内建設企業は 約 2,200 万円である. ただし, この数值は新設工事と維 持・修繥工事の両方を含む 7 . 表 -3 から, 規模の大き い公共工事は県外建設企業に発注する一方で，規模の 小さい公共工事は県内の建設企業に発注していること が読み取れる。このような発注傾向の背景には, 官公 需法の制約が国や地方自治体の発注者に働いていると 考えられる。例えば，県内建設企業に対しては，それら の企業の規模, 資本金などに応じて工事を細分化して 低額の請負契約金額で受注件数を増やすように努めて いる可能性がある。このように考えると，もともと規 模が小さい維持・修繥工事は県内建設企業が積極的に 受注する傾向にあるのは自然な流れである。また，県 外建設企業が受注した大型の建設工事の場合であって も, 1 次下請負の過半数は県内の中小建設企業を選定す るように発注者側からの指導が官公需法に基づき行わ れている. なお, 本研究では, 個々の工事の請負契約金 額などの詳細なデータを公的な統計データから獲得す 
ることは困難であったために，以上では，表 -2 , 表 -3 のように請負契約金額の平均值を用いて議論を進めて いる．詳細な議論を行うにあたっては，平均值のみな らず，個々の工事の請負契約金額の分布なども考慮す ることが望ましい点には留意されたい。しかしながら， 新設工事と維持・修繥工事，県外建設企業による受注 と県内建設企業による受注の請負契約金額の平均值に はそれぞれ明確な差があることは明らかであると考え， 発注傾向を把握するには平均值のみの議論で十分であ ると考える.

仮に，官公需法のような制度が存在しなかったとし ても， 1 件あたり 2,200 万円程度の維持・修繥工事に対 して, 県外の大手総合工事企業が積極的に営業活動を 行うことは困難である. 大手総合工事企業の技術力を 維持・修繥工事に反映させるためには，1 件当たりの 発注規模を増やし，工事規模を大きくして発注する必 要がある．当然のことながら請負契約金額が大きくな れば，大手総合工事企業が維持・修繥工事を請け負う ことができる．例えば，都市部における地下鉄の大規 模改造工事や, 高速道路, ダム, 原子力発電所などの 大規模かつ技術的難度の高い維持 - 修繥工事が該当す る. 近年の PFI（Private Finance Initiative）や BOT (Build, Operate and Transfer)，性能規定型複数年契 約といった新しい事業形態（複数の維持・修繥工事を 集約化して発注規模を増やすような試み）に関する検 討はこのような流れの中で生じてきたものと推測され る.しかし，5.で詳述するように，地方自治体が管理 する一般的な社会基盤施設群を対象とした維持・修縍 工事に対して PFI，BOT や性能規定型複数年契約を導 入することは，県内建設企業による受注が困難となり， 官公需法の適用下では困難であると言わざるを得ない。

通期決算の単独売上高が 1 兆円以上のある大手総合 工事企業 1 社に対するヒアリングを通して, 当該大手 総合工事企業の維持・修繥工事に対する将来展望を調 查した。図-8 は，ヒアリングの対象とした大手総合工 事企業の全売上高に対する各事業分野の比率を現状と 10 年後とで比較したものである. 重要な事業分野とし て, 海外建設事業, 国内建設事業（新設工事と維持・修 繕工事) の 2 つをあげている. 特に成長分野としては, 海外建設事業と維持・修繥工事をあげている.ただし， 想定している工事の内容は，土木工事に関しては，大 規模な社会基盤施設の総合的な補修や長寿命化対策で ある. 2020 年度には, 国内の新設工事は $19 \%$ ポイント 減少することが想定されており，その補填として海外 建設事業の売上高を $17 \%$ ポイント増加させることに重 点を置いている，維持・修繥工事は， $2 \%$ ポイント程度 の増額を見込んでいる．国内の新設工事の減少を，海 外と維持・修䋨工事で補填するという経営方針である

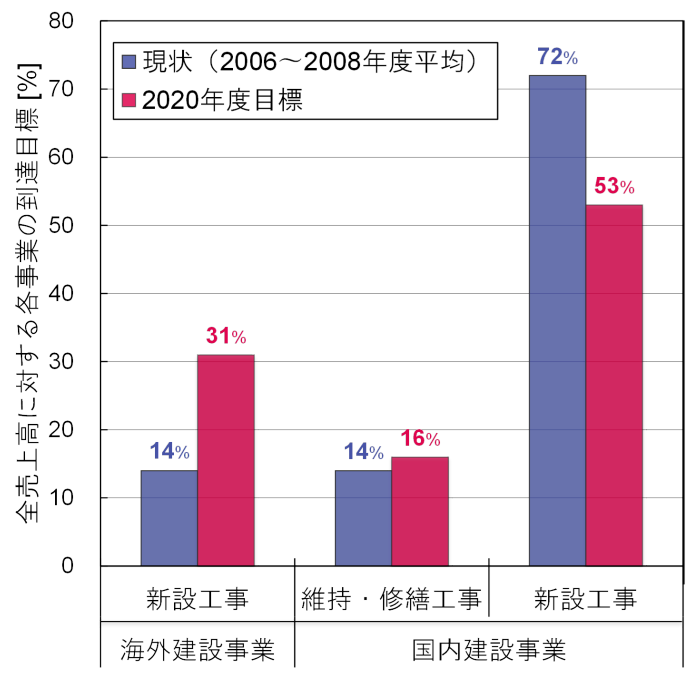

図-8 ある大手総合工事企業の将来展望

が, 海外工事の $17 \%$ ポイント増加目標に比べて, 維持・ 修繥工事は $2 \%$ ポイントの増加目標にとどまっている. さらに，受注すべき維持・修繥工事として，大規模な社 会基盤施設の総合的な補修（耐震，省エネなども含む） および長寿命化をあげていることから, 中小総合工事 企業では持ち合わせていない技術力を反映させた大規 模な維持・修緟工事に焦点を当てている。このような 背景を踏まえれば，一般的な維持・修繥工事のように， 請負契約金額が低く, 発注予定件数が非常に多い工事 に対しては，県内の総合工事企業や資本金 1,000 万円 以上 5,000 万円未満の専門工事企業が今後も中心的に 請け負っていくことになる.

\section{4. 階層別建設企業の受注実態調査}

\section{(1) ヒアリング調査の概要}

3. では，資本金別に 8 区分に階層化された建設企業 に対して, 地方自治体が発注する社会基盤施設の新設 工事および維持・修繥工事に対する受注件数や請負契 約金額についてマクロな調査を行った。その結果，一 般的な維持-修繥工事（数千万円規模）の大半は資本金 1,000 万円以上 5,000 万円未満の専門工事企業が受注し ていることが判明した。一方で，資本金 10 億円以上の 大手総合工事企業が，経営的な観点から維持・修繥工 事を重要分野に位置づけるためには，1件当たりの工事 規模を大きくする必要性があることを指摘した。ここ では，各資本金階層の中から，大手総合工事企業 2 社 （資本金 1,124 億円および 183 億円，以下 $\mathrm{A}$ 社および $\mathrm{B}$ 社），地元総合工事企業 2 社（資本金 4.5 億円および 3 億円，以下 $\mathrm{C}$ 社および $\mathrm{D}$ 社），機械化施工の専門工事 
企業 1 社（資本金 0.4 億円，以下 $\mathrm{E}$ 社）の合計 5 社の 建設企業を対象に, 2008 年から 2012 年度までの 5 年 間の請負契約金額別の受注件数に関するヒアリングを 実施した。ヒアリング調査期間は 2013 年 5 月から 6 月 である. また, 新設と維持・修繥の公共工事の受注件数 に限定し，民間工事や受注済みの設計変更工事および 海外の建設工事は除外した。ヒアリングでは, 請負契 約金額を 5,000 万円（0.5 億円）未満の工事から 50 億 円以上の工事の 8 区分に階層化し, 各区分における受 注実態を調査した。

\section{（2）請負契約金額の階層別受注件数}

図-9 の大手総合工事企業 $\mathrm{A}$ 社は, 8 区分に分類した 各請負契約金額階層に対してバランスよく受注してい る.ただし， 0.5 億円未満の工事の受注件数は全階層中 で最も低い $5.5 \%$ であり，50 億円以上の階層の工事の受 注件数割合 $(6.3 \%)$ よりも少ない. また，その工事内 容も都心部の大規模な社会基盤施設の新設工事に付帯 して施工される道路復旧, ガス, 下水, 水道などの地 下埋設物, 電気や通信用の架空線などの雑工事に過ぎ なかった. 5 億円以上 30 億円未満の工事の受注件数は 約 $46 \%$ で半数近くを占めている. 図-10 の大手総合工 事企業 $\mathrm{B}$ 社は，A 社と同様に各階層において比較的バ ランスよく受注しているが，特に 1 億円以上 10 億円未 満の工事の受注が主流となっており, 全体の約 $59 \%$ を 占めている. 30 億円以上の工事の受注が $6.6 \%$ と少ない 反面， 1 億円未満の工事の受注が約 $22 \%$ となっている. 図-11 の地元総合工事企業 $\mathrm{C}$ 社は, 3 億円未満の工事 が約 $78 \%$ を占め, 0.5 億円未満の工事の受注件数は約 $31 \%$ となっており, 地方都市を中心に 5 億円未満の社会 基盤施設の新設および維持・修繥工事をバランスよく 受注している. 図-12 の地元総合工事企業 D 社は, 0.5 億円未満, 0.5 億円以上 3 億円未満の工事で約 $94 \%$ 占 めている. 特に 0.5 億円以上 1 億円未満の工事の受注 件数は約 $56 \%$ を占めている. 図-13 の地元の専門工事 企業 $\mathrm{E}$ 社は, 0.5 億円未満, 0.5 億円以上 3 億円未満の 工事で約 $96 \%$ を占めており, 特に 0.5 億円未満の工事 の受注件数は約 $60 \%$ を占めるに至っている. 以上のよ うに, 本研究では 5 社の総合および専門工事企業を対 象にヒアリングを実施した. サンプル数は少ないもの の, 受注件数の傾向を把握するには十分であると考元 ている，言い換えれば，資本金をもとにした企業の規 模を逸脱した形で, 工事を受注することは困難である. 3. のマクロな傾向だけでなく, 特定 5 社を対象にした ミクロな傾向においても, 大手総合工事企業は請負契 約金額の大きな新設工事, 地元総合工事企業や専門工 事企業は請負契約金額 1 億円未満の維持・修繥工事を 受注していることが理解できる.

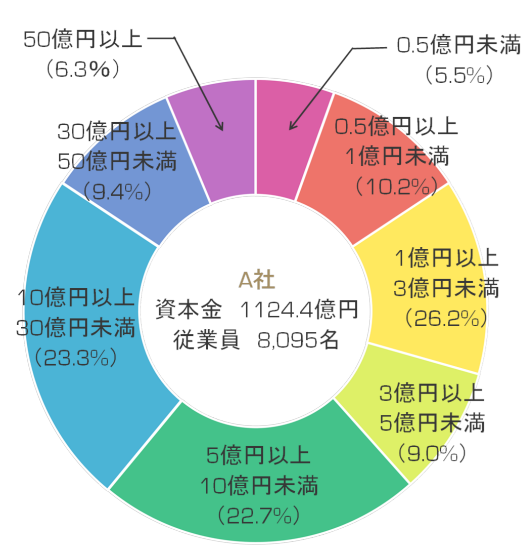

図-9 A 社請負契約金額階層別受注件数割合

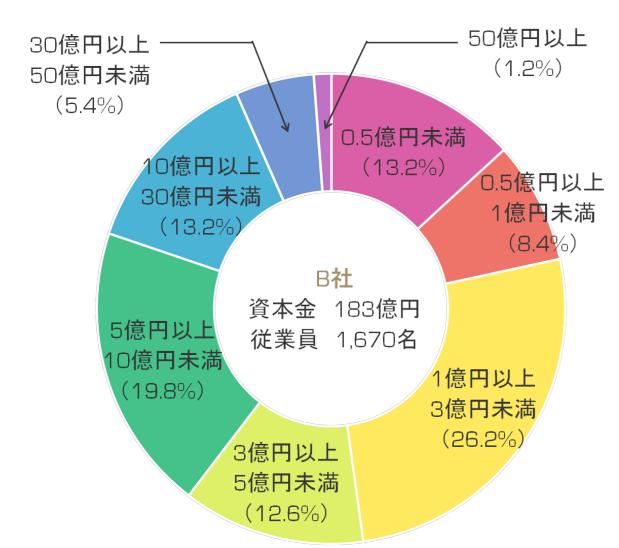

図-10 B 社請負契約金額階層別受注件数割合

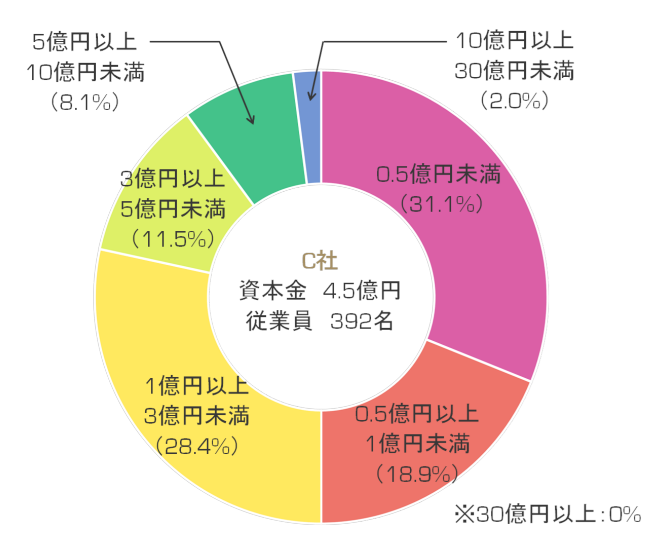

図-11 C 社請負契約金額階層別受注件数割合

一般的に，大手総合工事企業は都心に本社があり，各 地方の支店が主導で請負契約金額の高い新設工事を中 心に営業活動を行っていることから, 維持・修繥工事 


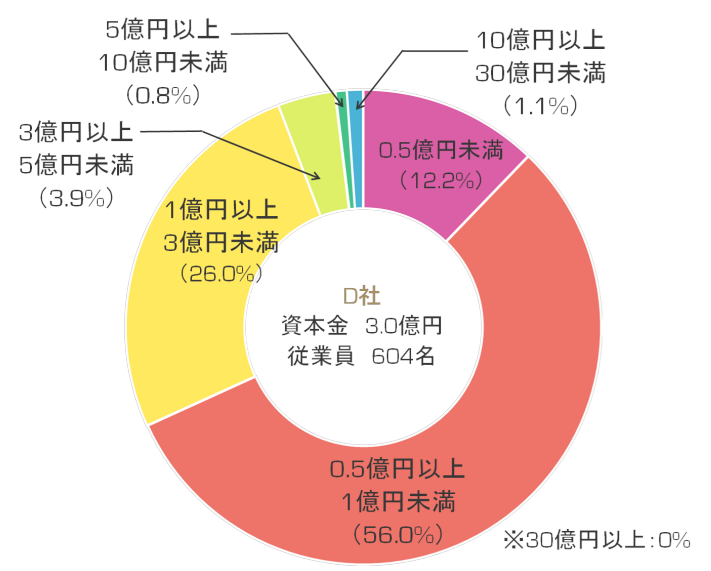

図-12 D 社請負契約金額階層別受注件数割合

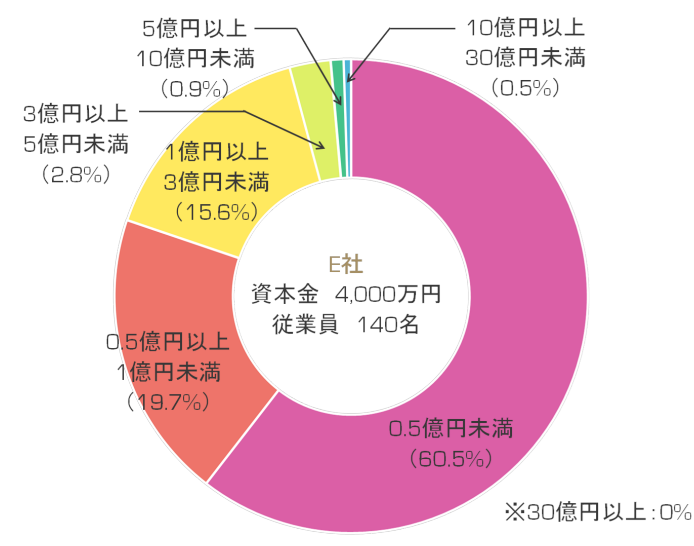

図-13 E 社請負契約金額階層別受注件数割合

に対する優先順位は低くなる。このことと，上記のヒ アリング結果から, 維持・修繥工事の施工主体は, 地元 総合工事企業や直営施工を基本にした地元専門工事企 業であることがわかる. しかし, 専門工事企業が維持・ 修繥工事において中心的な役割を担うためには，多く の課題が残っているのも事実である. 例えば, 専門工 事企業の中には表-1に示した 21 業種を主要な業務と しつつも, 土木一式工事や建築一式工事を請け負う企 業も存在する。 そのような専門工事企業は, 実施工の みならず, 工事契約, 発注者協議, 基本設計, 設計変更 協議, 担保期間内の補償など, 建設企業が従事する全 ての業務を包括する総合技術力 ${ }^{22)}$ を積極的に学んでい く姿勢が必要となる.

\section{（3）専門工事企業の経営状況}

今回のヒアリングを通して, 本研究で着目する専門 工事企業の経営状況を把握することができた。ただし， それらを実績データ等を用いて定量的に考察すること
土木学会論文集F4(建設マネジメント), Vol. 72, No. 3, 84-101, 2016.

はできなかった。しかしながら, 専門工事企業自体が学 術的に着目される機会がこれまでなかったこともあり， それらも貴重な情報であると判断し，以下に整理する.

すでに述べたように, 専門工事企業は, 1959 年頃ま で旧建設省などの管理・監督による直轄施工体制のもと で現在の総合工事企業への労務提供を行っていた. 総合 工事企業による直接施工体制への移行後は, 業種別に 分けられた工事を総合工事企業の指示に従いながら担 当した. その後は, 建設投資のさらなる拡大に伴って, 建設工事に占める専門工事企業の下請負完成工事比率 は高まっていった，工事比率の増加過程において，例 えば機械化施工を専門とする専門工事企業は, 積極的 な設備投資を行い，施工機械を自社で保有することに より技術力を高め, 請負業務に関する自主管理体制の 確立を目指してきた。したがって, 他社と差別化し得 る自社の専門技術に関しては，事業規模や事業方針の 相違はあるにせよ, 各社ともに経営資源（機械, 資材, 人材）を概ね整えている状況にあった。しかし，近年に 見られる低価格優先の受注競争においては, 施工機械 などの有形固定資産や, 労務者（施工機械のオペレー ター等）の直接雇用にかかわる運用管理費用が財務的 な負担となってきている.このような中で, 施工機械 等を含めた経営資源保有率を低く抑え, 固定費用をあ まり必要としない間接管理を主体とする専門工事企業 も存在し始めている. すでに経営の合理化を目的とし て, 施工機械等の経営資源保有率を抑制している元請 負の総合工事企業にとっては, 新設工事にせよ, 維持・ 修繥工事にせよ, 建設産業は一般的に受注産業である. しかしながら, 機械化施工が主流となる中で, 実施工 を請け負う専門工事企業においては, 常時, 施工機械 を保有しなければならないことに加え, そのオペレー 夕を雇用する必要があることから, 建設産業は見込み 生産（先行投資）を伴う市況産業であるといえる.

すでに述べたように, 専門工事企業の中には, 再下 請負建設企業に実質的な業務を発注することにより自 社の経営状況の改善を試みる企業も存在する. このよ うな専門工事企業が増加すると, 専門性の高い技術力 を有する専門工事企業の経営はさらに厳しくなる。そ の一方で, 専門工事企業が施工機械を保有することに 対しては, 緊急の維持・修繥工事や事故・災害復旧など を見据えた場合に, 行政および地元住民から強い要望 があることも事実である. 厳しい経営状況にありなが ら, 専門工事企業にとっては事故・災害復旧を通じた地 元貢献も重要な責務であり, 施工機械等の保有率を単 純に低減させることはできない。また, 建設市場では, 社会資本整備重点計画の見直しが継続して行われてい るが, 民間市場も含め, 少子・高齢化や環境への意識の 高まり, $\mathrm{PPP} / \mathrm{PFI}$ 等の新規事業の必要性, 維持管理 · 
リフォーム工事等の比重の増加など，事業を取り巻く 周辺環境の変化に柔軟に対応することが求められてい る. 特に, 社会基盤施設の維持・修繥工事は, 新規建設 とは異なり典型的な小規模分散型事業であることに加 え，社会基盤施設の損傷の要因となる施工状況や被災 履歴，さらには周辺環境を熟知している地元の総合工 事企業や地域に根ざした熟練した人材を擁する施工力 のある専門工事企業の参画が不可欠であり，それらを 中心とした施工体制が重要となる.

\section{5. 維持・修繥工事に関する実践上の課題}

\section{（1） 維持・修繥工事と官公需法}

2011 年度の 47 都道府県における維持・修繥工事 1 件 あたりの請負契約金額は平均で約 2,800 万円であった. 一方で, 全件数は 36,262 件, 請負契約総額は 1 兆 10 億 円であり, 維持・修繥工事の 1 都道府県あたりの平均発 注金額は 213 億 2,000 万円である ${ }^{7)}$.したがって，維 持・修繥工事のような小規模工事を集約化して発注規模 を大きくした上で，1）委託設計を大手コンサルタント 企業に請け負わせ，2）施工に関しては大手総合工事企 業と複数年契約を交わすような事業形態が考えられる. 実際に維持・修繥工事のように発注規模の小さい工事に おいては全国的に不調・不落が増加しており，このよう な事業形態は実務的に有効な手段であるとの指摘もあ る. 国内外の大手コンサルタント企業や大手総合工事 企業であれば， 1 都道府県あたりの維持・修繥工事の設 計委託業務や施工を一手に請け負うことができる技術 力と人員を保持している. 発注者側にとっても, 維持・ 修繥工事を集約化させることにより，契約等の事務処 理を格段に軽減できる．また，施工管理業務について も，例えば従来の仕様規定ではなく，性能規定型契約 を締結することにより，大手総合工事企業の自主管理 体制で業務の効率化を図ることが可能となる．実際に， 社会基盤施設の維持・修繥工事に関して，PFI や性能 規定型の複数年契約など，欧米での先行事例を参考に， 国内でも試験的導入がなされている。しかし，現実的 には官公需法の適用下において，このような大型契約 の普及・定着は困難と言わざるを得ない側面がある.

維持・修繥工事の発注業務において，上述したよう な PFI や複数年契約で維持・修繥工事の集約化を推奨 する考え方もあるが，国などは官公需法の適用下にお いて，大手総合工事企業の参入を前提とした PFI や複 数年契約には消極的とならざるを得ない側面があるこ とも事実である. 大手総合工事企業や大手コンサルタ ントが，1件あたりの受注規模が小さい維持・修繥工事 を集約化せずに個々に請け負うことは経営判断として 困難であると 3.で指摘した。したがって，官公需法を
前提とした現状では，社会基盤施設の維持・修繥工事 で，地元の総合工事企業や専門工事企業がそれぞれ施 工管理や実施工を中心的に担うような枠組みを採用す ることにより，時間と費用の縮減，工事の効率化を図 ることができると考えられる.

\section{（2）維持・修繕工事の不完備性に着目した専門工事企 業の役割}

3., 4. で述べたように, 維持・修繥工事の主要な担 い手は，地元の専門工事企業となる．このとき，2.(5) で述べた内容を考慮すると, 地元の建設企業, 特に技 術力の高い専門工事企業の参画を通して, 社会基盤施 設の現状に則した維持・修繥計画を立案できると考え られる.このことは，2.(5) で述べた内容を含め，4.で 対象とした企業を含む複数の専門工事企業へのヒアリ ングを通じて，著者等の主張の妥当性を確認している. 実際に，維持・修繥工事においては，工事完了後に急 速な再劣化が生じることも少なくなく, 単純に対象と なる損傷や劣化を修繥するだけでは不十分な場合も多 い。このような経緯を踏まえて，概略，予備，詳細設 計などの設計業務から, 維持・修繥工事の施工までを 一括して発注することによって, 不完備性が大幅に軽 減される. 国土交通省の「設計・施工一括及び詳細設 計付工事発注方式実施マニュアル（案）」23)において も, 設計・施工一括発注方式の適用対象の 1 つとして 維持・修繥工事が推奨されている. また, 実際に, 設 計・施工一括発注方式を採用することにより，質の高 い工事が実施された事例も，その数は少ないが存在す る 24)-26)。ただし，これらの参考文献では総合評価方 式に主眼が置かれその有用性が議論されており, 維持・ 修繥工事を設計・施工一括発注方式で実施することに よる不完備性の軽減に対しては言及されていない.

新設工事の設計は高い技術力を有する企業であれば 十分に実施できる.しかし，どの企業が請け負ったとし ても, 施工の過程で生ずる不完備性を予め軽減するこ とは難しい。一方で，維持・修繥工事に関しては，その 不完供性を軽減することは可能である.すなわち, 維 持・修繥工事の対象となる社会基盤施設の構造, 使用· 環境条件, 修繥や被災の履歴を供用時点から把握して いる企業が設計を請け負い, 施工を行うことが重要で ある.この点に新設工事と維持・修繥工事の情報に関 する不完備性の相違がある．しかしながら，その実現 には現行の設計・施工分離発注方式から設計・施工一括 発注方式への転換が不可欠である．維持・修繥工事の 一部においては, 点検と簡易修繥の一括発注が試行的 に実施されている。しかし，その際には点検と修繥が 同一企業で実施されることから，モラルハザード（点 検結果を実際よりも悪く評価することによって修繥箇 


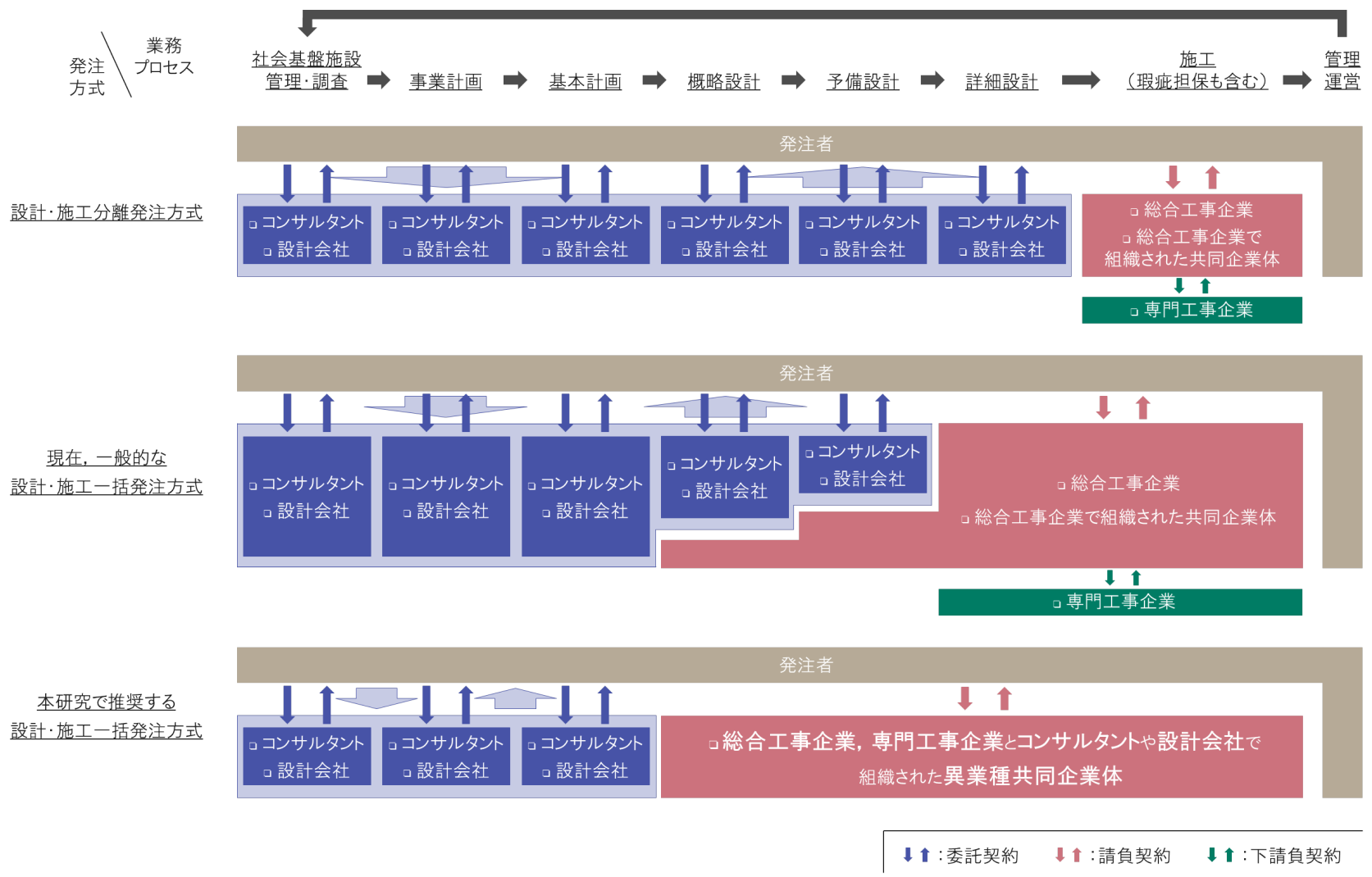

図-14 維持・修繥工事における各発注方式の業務担当

所を増やし，自ら修繥工事を実施するような行為など） が発生する恐れが指摘されている. 点検結果を踏まえ て修繒に移行する段階において, 点検結果の妥当性を 評価する仕組みが必要である（ただし，管理者が妥当 性評価に深く関与するようでは，一括発注の良さも軽 減される）。これは設計と施工を一括発注する場合に も同様である. 5.(1) で述べたように同質な小規模工事 を単に集約化して発注規模を大きくするよりも, 官公 需法の適用および維持・修繥工事の特徵を踏まえると, 同一の社会基盤施設に対して設計や施工などの工事プ ロセスを集約化させる設計・施工一括発注方式のよう な発注方式が重要であると考える。

\section{(3) 設計・施工一括発注方式}

国土交通省の土木事業では,「土木設計業務等委託契 約書」第 7 条（付録 II）等の規制により，1995 年 7 月 から各種設計業務の受託者が，例えば当該契約におけ る第三者である大手総合工事企業等に設計業務の一部 を再委託することを禁じている。これにより設計・施 工分離が明確化され, 今日に至るまで新設工事では設 計・施工分離発注方式が主流となっている. 社会基盤 施設に関する管理者（発注者）の業務範囲は, 新規建
設の企画・計画から詳細設計，施工の監修・監理，管理 運営, 点検など多岐にわたるが, それらの業務全てを 管理者自ら実施しているわけではない. 特に, 社会基 盤施設の管理・調査や各種設計（概略, 予備, 詳細）は 設計委託業務としてコンサルタントや設計会社に, 施 工業務は請負業務として総合工事企業に発注する場合 が多い. 図-14 は, 維持・修繥工事を対象とした設計・ 施工分離発注方式 (現状では, 設計・施工分離発注方式 は維持・修繥工事においても広く採用されている）と 設計・施工一括発注方式の枠組みを示す.

はじめに，図-14 上段に示す設計・施工分離発注方 式で行われる維持・修䌜工事における設計委託業務で は, 発注者から業務を受託したコンサルタントや設計 会社が発注者の設計意図に従って各種設計（概略, 予 備, 詳細）を行い, 設計図面を作成する. なお, 社会基 盤施設の管理・調査から詳細設計までの各業務プロセ スの業務担当は, それぞれのプロセスで異なるコンサ ルタント, 設計会社に委託される場合や複数のプロセス （例えば，概略設計から詳細設計まで，など）が 1 つの コンサルタント, 設計会社に委託される場合, さらには コンサルタント, 設計会社に委託せずに発注者自身で 行う場合も存在する。このように詳細設計まで実施し 
たのち，総合工事企業が施工業務を受注する．受注し た総合工事企業は業務の一部を専門工事企業に下請負 発注する．なお，下請負契約に関して，図-14では，2 次下請以降の再下請建設企業は省略している．さらに， 複数の総合工事企業，あるいはそれらに専門工事企業 を加えた組織で構成された共同企業体が施工業務を請 け負う場合も存在する．施工が完了した後は，発注者 により当該施設の管理・運営が行われる.このような 業務プロセスのうち，工事施工に係わる詳細設計業務 （施工計画，仮設計画，工程計画等）については，第三 者への再委託禁止以前には，コンサルタントは特定の 総合工事企業からの協力要請の申し出を受けて当該業 務の再委託を行い，現場の実施工に耐え得る完成度の 高い計画を作り上げていた。その当時，再委託を受け た総合工事企業が作成した設計図書（特に施工計画や 工程計画）は精度が高く, 現在頻繁に発生している設 計図書の違算，施工方法や工程計画の不備は極端に少 なかった，再委託にはこのような利点がある反面，元 請負であるコンサルタントが再委託先である総合工事 企業に設計を丸投げするという事態が発生した．結果 的に, このような事態を経て, 設計・施工一括発注方 式が禁止され，設計・施工分離発注方式へと切り替わ るに至った。

一方，維持・修繥工事における設計・施工一括発注方 式（図-14 中段, 下段）は, 発注者の事業計画に基づ き，社会基盤施設の構造形式や主要諸元も含めた設計 業務と施工業務を一括で発注して，民間企業の優れた 技術を活用し，設計・施工の品質，設計の合理性，施工 の効率性を高めることができる利点がある．現在，設 計・施工一括発注方式（図-14 中段）では，一般的に 設計業務と施工業務を一括して総合工事企業あるいは 総合工事企業で組織された共同企業体に発注し, 主に 総合工事企業の設計部門が設計を行う。このとき，建 設企業単独で設計・施工業務を受注する場合は， 3.や 4.で言及したように，その請負契約金額が大きいため に，地元の専門工事企業が受注できず，維持・修絟工事 の不完備性が十分に軽減できない可能性がある。一方, 本研究で推奨する設計・施工一括発注方式（図-14 下 段）は，設計・施工業務をコンサルタントと建設企業か らなる共同企業体により行うことが特徴である. 図-14 に示すように，本研究で推奨する設計・施工一括発注 方式では，従来の方式（同図上段，中段）では下請負 建設企業として業務を受注していた専門工事企業も含 めて設計・施工一括業務を受注する異業種共同企業体 が組織されている点と業務プロセスの内で概略設計ま で含めた設計・施工業務を異業種共同企業体が受注し ている点が，図-14 上段，中段の従来の発注方式と明 確に異なる点である（なお，同図下段においても，従
来の方式で 2 次下請以降であった再下請建設企業は省 略している.）。これにより, 資本金が少ない地元の専 門工事企業も発注者と直接的に契約を行うことができ, さらには，専門工事企業の有する知見を詳細設計のみ でなく概略設計から工事に反映することが可能となる ため, 維持・修繥工事の不完備性が軽減し得ると考え る.さらに，図-14下段の方式では，官公需法にも容 易に適応できると考える. 設計・施工一括方式におけ る共同企業体の有用性に関しては，多少の既往研究 ${ }^{27)}$ が存在するが，維持・修繥工事に着目し，官公需法を 考慮している点に本研究の独自性がある. 推奨する設 計・施工一括発注方式を採用することにより，建設企業 （特に，地元建設企業）も含めて維持・修繥工事の設計 業務に参画することが可能になる。このとき，コンサ ルタントと建設企業とは再委託・受託の関係ではなく, 共同企業体として対等な関係にある。ただし，共同企 業体を組織することによって,「土木設計業務等委託契 約」第 7 条等の規制に形式上は抵触しないようにして, 実質的には建設企業に設計業務を丸投げするような行 為の発生を防止する必要がある。なお，本研究におけ る設計・施工一括発注方式では，既述したように，概 略設計と予備設計に加えて, 詳細設計までを範疇に含 めることを想定している，すなわち，社会基盤施設の 構造形式や主要諸元, 構造一般図などを確定した上で, 施工のために必要な仮設をはじめ, 詳細な設計と施工 を一括で発注する詳細設計付工事発注方式を想定して いる. 現状は, 維持・修繥工事の発注業務においても, 設計・施工分離発注方式が多い。維持・修繥工事では, 既設の社会基盤施設を供用させながら並行して工事を 進めることが多く，現場を充分に踏査，観察した上で, 設計を行う必要がある。しかし，設計・施工分離発注 方式では，設計と施工の一貫性が取れない場合も多く， 工期延長や費用増加につながるケースも確認できる.

震災復興および東京オリンピック関連の公共事業の 増加を受け，入札の不調（入札参加者がゼロ，または規 定に足りず不成立）や不落（入札価格が全て予定価格 を超過するなどして落札者が決まらない状態）が全国 的に課題となっている. 特に地方自治体の新設および 維持・修繥工事や東日本大震災の復興工事では, 工事 の入札で不調や不落が頻発している．それぞれの発注 機関は入札制度の簡易化や指名競争入札の再導入など, 対策に苦慮しているのが現状である。このように工事 の入札で不調や不落が頻発する要因としては，1）対象 となる建設工事に応じた生産性データーベース（作業 歩掛）と公共工事の積算代価の根拠となる国土交通省 土木工事標準歩掛とが乘離していること，2）公共工事 設計のための官積算単価（労務や資材）と実勢の市場 単価とが乘離していること，3）遠隔地からの資機材調 
達のための輸送費用や，建設機械の損料単価の増加が 現状に反映されていないこと，4）賃金または物価変動 に基づく請負金額の変更 (スライド条項, インフレ条 項など）のための算定方式が実情と合致していないこ と，5）設計・施工分離発注方式で作成された設計図書 の不具合により設計変更が繰り返されることなどがあ げられる。そのため, 維持・修䌜工事に関しても, 新 設工事と同様に不調・不落を防ぐために，ある程度の 請負金額を確保して発注を行う必要がある。このとき, 維持・修繥工事の発注規模を大きくするために, 複数 の工事を一括して単純に請負金額を大きくすると，大 手建設企業などの他の都道府県の建設企業が参入して, 地元の建設企業の受注が困難になる.さらに設計・施 工分離発注方式の工事となれば, 不完備性を軽減し得 る地元の建設企業ならではの技術を最大限に活用する ことができない.さらに, 官公需法を満足しなくなる 可能性もある。一方, 図-14 で提案した設計・施工一 括発注方式は, 概略設計, 予備設計, 詳細設計にまで 及ぶ設計委託と工事の施工を束ねて共同企業体の担当 業務の発注規模を増やすことに特徵がある。このとき， 共同企業体に地元の企業を含める（官公需法により推 奨されている）ことにより，不完備性を軽減しながら， 工事の不調・不落を防ぎ，同時に社会基盤施設の品質 や耐久性が高められ円滑に維持・修繥工事を進めてい くことが可能となる.

\section{（4）事業形態と専門工事企業の役割への実務的示唆}

2001 年に閣議決定された「公共工事の入札及び契約 の適正化を図るための措置に関する指針」28)において, 共同企業体の事業組織体は，1）特定建設工事共同企業 体，2）経常建設共同企業体，3）地域維持型建設共同 企業体の 3 方式に分類されている. 各共同企業体の詳 細については付録 III を参照されたい. 本研究で言及 した維持・修繥工事の設計・施工一括発注方式を担う 事業組織体については, 地域維持型建設共同企業体を 基本として, 共同企業体構成員に施工担当の建設企業, これとは別の異業種企業であるコンサルタントや実施 工を担当する地元の専門工事企業が含まれるような異 業種共同企業体 ${ }^{29}$ ）(以下，地域維持型建設共同企業体 (異業種)）が望ましいと考える。地域維持型建設共同 企業体（異業種）は，1）官公需法への適応，2）継続的 な協業関係を通じた維持・修繥工事の実施体制の安定 確保，3）専門工事企業の参画と, 特殊工事の分離発注 と同様に専門工事企業に対する発注者の直接的な発注, 4）共同企業体構成員に建設企業の他, 設計事務所やコ ンサルタント, 機械や電気メーカーの参画, が可能と いう特色を有する，なお，経常建設共同企業体は，経 営規模が小さい建設企業が共同企業体を組み, 比較的
大きな建設工事を受注することによって受注機会の確 保や利益の拡大を図るものである. したがって, 維持 · 修繥工事における設計・施工一括発注方式には適さな い. 現行の制度において, 地域維持型建設共同企業体 を異業種企業も含み組織することは可能であり, 本研 究で推奨する設計・施工一括発注方式における共同企 業体が維持・修繥工事において採用されるための枠組 みは整っているといえる. しかし, 実際の採用事例は 現段階では極めて少ない。その理由として，1）設計 · 施工一括発注方式や地域維持型建設共同企業体（異業 種）の存在や利点が周知されていないこと，2）地域維 持型建設共同企業体（異業種）を組織する際の事務手 続きが煩雑となること，3）設計・施工一括発注方式自 体の事務手続きも煩雑となる場合があること ${ }^{30)}$, など があげられる. 本研究で得られた知見を周知し, 地域 維持型建設共同企業体 (異業種) による設計・施工一括 発注方式の採用事例を段階的に増加させることにより, 維持・修繥工事の効率化と品質向上を図っていくこと が望ましいと考える. なお，このような著者等の主張 は, 国土交通省の見解 ${ }^{31), 32)}$ とも整合的であると考え る. 国土交通省は, 地域維持型建設共同企業体の対象 工事として社会資本の維持管理のために必要な工事の うち, 災害応急対応, 除雪, 修繥, パトロールなど地 域事情に精通した建設企業が当該地域において持続的 に実施する必要がある工事（維持管理に該当しない新 設・改築等の工事を含まない）を，地域における担い 手確保が将来的に困難となるおそれがあるため地域維 持型建設共同企業体を競争に参加させる必要がある工 事としている.

社会基盤施設の新設工事の元請負である大手総合工 事企業は, 工事の大部分を下請負の専門工事企業に任 せているために, 詳しい施工過程を把握していない場 合が少なくない. コンサルタントについても常態的に 再委託が行なわれていたために, 詳細設計と現地の実 構造物との相違を精緻に把握することには限界がある. このような理由で, 新設工事の際に設計や施工を請け 負った企業に, 維持・修繥工事を発注した方が効率的 であるという単純な考え方には疑問が残る. 工事地域 の地元に密着したコンサルタントや建設企業は, 地域 の社会基盤施設の整備や維持管理の担い手であり, 地 震, 津波, 台風, 豪雨等の災害時における防災の要と して地元にとっては久かすことのできない存在である. また, 規模の大きい社会基盤施設の新設工事では, 大 手総合工事企業が中心となって工事を進めるのが一般 的であるが，その工事の竣工後に下請負として直接的 に施工に従事するのは, 地元の総合工事企業や専門工 事企業であることが多い。これらの地元の総合工事企 業や専門工事企業の中には, 当該施設の新設工事での 
経験から，その劣化・損傷に対する地域的な要因や施 工的要因等に精通し, 現在供用中の社会基盤施設の維 持・修繥についての詳細情報を把握している技術力を 有した建設企業も多く存在する。この点は, 著者等の 経験に基づく考えも含まれるが，本研究でのこれまで の議論から維持・修繥工事は地元の建設企業が担当す る場合が多い傾向にあることは明らかであり，仮に新 設工事を担当した地元の総合工事企業や専門工事企業 が当該施設の維持・修繥についての詳細情報を保持し 続けていない場合には，それらの情報を適切に記録し， 保持し続けることが，今後，維持・修繥工事を円滑か つ効率的に行うために必要不可欠な地元総合工事企業, 専門工事企業の役割であると考える. また， 3. で述べ たように, 維持・修繥工事の施工主体は, 受注件数や請 負契約金額から判断して資本金 1,000 万円から 5,000 万 円程度の地元専門工事企業が適切である.ただし, 地 元の専門工事企業の課題としては, 大手総合工事企業 の下請負から脱却して, 維持・修繥工事に主体的に取り 組む方向に経営方針を転換することが重要である。そ のためには元請負業務の実施が不可欠であり,「土木一 式工事」および「建築一式工事」の建設業許可の取得 が最低必要条件となる。下請負業務と明らかに異なる のは, 発注者との直接対話や, 専門技術だけでなく種々 の協議事項が日常業務として行われる点であり, 総合 的な建設マネジメント能力の向上が求められる.

\section{6. おわりに}

本研究では, 社会基盤施設の維持・修繥工事に着目 し，特に専門工事企業に焦点を当てた形で，今後専門 工事企業が維持・修繥工事において果たすべき役割と それを支える制度設計について検討を行った。はじめ に, 新設工事と維持・修繥工事の完成工事高等の推移と 維持・修繥工事高の割合を分析し, 新設工事の請負契 約金額や建設投資額の減少にも係わらず維持・修繥工 事が増加傾向にあることを示した。つぎに, 統計調査 データの分析やヒアリングを通して, 維持・修繥工事 は, 1 件当たりの請負契約金額が低い小規模分散型のプ ロジェクトが大多数であり, それらに経営的な観点か ら適応できる建設企業群としては資本金 1,000 万円以 上 1 億円未満の建設企業であることを指摘した。なか でも中心的な役割を果たすべき建設企業は資本金 1,000 万円以上 5,000 万円未満の階層, すなわち専門工事企 業のような地元の建設企業であると位置付けた。また， 官公需法の適用下では維持・修繥工事の単純な大型化 は困難であることを指摘した。さらに, 緊急的な点検 や修繥, 事故・災害時の迅速な対応を考慮しても, 地 元に根ざした専門工事企業が維持・修繥工事を担うこ
とが最善であることも言及した。 加えて, 地元で長年 に亘り事業を営み, 周辺の社会基盤施設の被災履歴を 把握している専門工事企業であれば, 維持・修繥工事 の不完備性を低減できることも指摘した。 さらに, 維 持・修繥工事において専門工事企業が中心的な役割を 果たすためには, 契約方式として現行の設計・施工分 離発注方式ではなく, 地域維持型建設共同企業体（異 業種）による設計・施工一括発注方式が望ましいこと も述べた. 地元のコンサルタント, 総合工事企業, 専門 工事企業が共同企業体を組織して, 概略設計から施工 までを請け負う設計・施工一括発注方式を採用すれば, 民間企業の優れた技術と経験を活用し, 品質確保, 合 理的な設計, 維持管理の効率性が期待でき, 社会基盤 施設の安全性と長寿命化に大きく貢献していくと考え る. また, 実際に設計・施工一括発注方式を担う地域 維持型建設共同企業体（異業種）を組織し活用するた めの枠組みは整理されている。一方で, 専門工事企業 にはこれまでの自社技術の専門性を高める努力のみな らず, 安全衛生管理や災害防止を含め, 受注した工事 全体を管理するための総合技術力を養うことも求めら れる. 東日本大震災の復興工事, 東京オリンピック開 催に伴う老朽化施設の更新など, 公共工事は増加傾向 にある.これにより, 本研究で指摘した問題は必然的 に解消される可能性がある. しかし, それは近視眼的 な理解であり, 社会基盤施設の維持・修繥を長期的な観 点で見据えた制度設計が必要となる。

謝辞: 本研究の一部は, 日本学術振興会科学研究費助 成事業「特別研究員奨励費」により実施された。ここ に記して感謝の意を表する.

\section{付録 I 官公需法}

「官公需についての中小企業者の受注の確保に関する法 律」(昭和 41 年 6 月 30 日法律第 97 号)（最終改正 : 平 成 19 年 5 月 25 日法律第 58 号)

(目的) 第 1 条: この法律は, 国等が物件の買入れ等 の契約を締結する場合における中小企業者の受注の機 会を確保するための措置を講ずることにより, 中小企 業者が供給する物件等に対する需要の増進を図り, も つて中小企業の発展に資することを目的とする.

(定義) 第 2 条：この法律において「中小企業者」と は, 次の各号のいずれかに該当する者をいう.一.資本 金の額又は出資の総額が三億円以下の会社並びに常時 使用する従業員の数が百人以下の会社及び個人であっ て, 製造業, 建設業, 運輸業その他の業種（次号から 第二号の三までに揭げる業種及び第三号の政令で定め る業種を除く.）に属する事業を主たる事業として営む 
もの.

（受注機会の増大の努力）第 3 条: 国等は, 国等を当 事者の一方とする契約で国等以外の者のする工事の完 成若しくは作業その他の役務の給付又は物件の納入に 対し国等が対価の支払をすべきもの（以下「国等の契 約」という.）を締結するに当たっては，予算の適正な 使用に留意しつつ, 中小企業者の受注の機会の増大を 図るように努めなければならない。この場合において は, 組合を国等の契約の相手方として活用するように 配慮しなければならない。

\section{付録 II 土木設計業務等委託契約書}

第 7 条（一括再委託等の禁止）受注者は，業務の全 部を一括して, 又は設計図書において指定した主たる 部分を第三者に委任し, 又は請け負わせてはならない. 2. 受注者は, 前項の主たる部分のほか, 発注者が設計 図書において指定した部分を第三者に委任し, 又は請 け負わせてはならない．3. 受注者は, 業務の一部を第 三者に委任し, 又は請け負わせようとするときは, あ らかじめ, 発注者の承諾を得なければならない.

\section{付録 III 共同企業体}

2001 年に閣議決定された「公共工事の入札及び契約 の適正化を図るための措置に関する指針」では，建設 企業が単独で受注および施工を行うような通常の場合 とは異なり, 複数の建設企業が 1 つの建設工事を受注 し施工することを目的として形成する事業組織体を共 同企業体と定義している，また，国土交通省は共同企 業体制度について，1）特定建設工事共同企業体，2）経 常建設共同企業体，3）地域維持型建設共同企業体の 3 方式を定め，それらの共同企業体の運用基準について， 共同企業体運用準則（共同企業体の在り方について（昭 和 62 年中建審発第 12 号）別添第二）に従うことを示 している．特定建設工事共同企業体は，大規模かつ技 術難度の高い工事の施工に際して, 技術力等を結集す ることにより工事の安定的施工を確保する場合等, 工 事の規模・性格等に照らし, 共同企業体による施工が 必要と認められる場合に工事ごとに結成する共同企業 体をいう. 経常建設共同企業体は, 中小・中堅建設企業 が継続的な協業関係を確保することにより，その経営 力・施工力を強化する目的で結成する共同企業体をい う. 単体企業と同様, 発注機関の入札参加資格審査申請 時（原則年度当初）に経常建設共同企業体として結成 し，一定期間，有資格業者として発注機関に登録する。 一般的に企業規模の小さい建設企業が共同企業体を組 織して単体では受注できない規模の大きな工事を受注
することが狙いで受注機会の拡大につながり，利益の 向上に寄与すると考えられている. 地域維持型建設共 同企業体とは，地域の維持管理に不可欠な事業におい て，継続的な協業関係を確保することによりその実施 体制の安定確保を図る目的で結成する共同企業体をい う. 発注機関の入札参加資格申請時または随時に地域 維持型建設共同企業体として結成し，一定期間，有資 格業者として登録される，ある企業が，登録機関期間 ごとに結成・登録することができる地域維持型建設共 同企業体の数は, 原則 1 つとし, 継続的な協業関係を 確保するものとする. なお, 地域維持型建設共同企業 体については，ある企業と地域維持型建設共同企業体 との同時登録ならびに経常建設共同企業体および特定 建設工事共同企業体と経常建設共同企業体との同時結 成および登録は可能である ${ }^{28)}$.

2000 年に国土交通省発表の「専門工事業イノベーショ ン戦略」で示された異業種共同企業体は, 公共工事, 民 間工事を問わず十分活用できる建設生産システムであ る. 総合工事企業と専門工事企業および複数の専門工 事企業が共同企業体を構成する事業組織体で, 分離発 注方式と同様に専門工事企業に対して発注者が直接発 注する形式である。一括請負契約方式に比べてコスト が透明になり, 専門工事企業からの VE 提案も促進さ れるほか, 分離発注方式に比べると発注者側の事務手 続きが軽減され, 専門工事企業や相互の連携が図られ るなどの大きな長所があるにもかかわらず, 公共工事 の一部で小規模に試行されているのが現実である. 今 後, 異業種共同企業体の構成員としては, 総合工事企 業や専門工事企業の組合せだけでなく設計事務所やコ ンサルタント, 機械メーカー等の参画も視野に入れる ことができる ${ }^{29)}$.

\section{参考文献}

1）建設業法別表第一.

2) 総務省 : 日本標準産業分類, (平成 25 年 10 月改定) (平 成 26 年 4 月 1 日施行)，2013.

3) 草柳俊二, 五艘隆志, 浜田成一: 契約理論と実践に基づ く建設産業の事業遂行システム構築に関する研究, 建設 マネジメント論文集，Vol.16, pp.183-196， 2009.

4) 東京商工リサーチ : 中小企業庁委託調査平成 26 年度発 注方式等取引条件改善調査事業報告書, 2015 .

5）国土交通省 : 下請契約及び下請代金支払の適正化並びに 施工管理の徹底等について，2015。

6) 国土交通省 : 平成 21 年度国土交通白書, 2010 .

7）国土交通省総合政策局:建設工事受注動態統計調査, 19902013.

8）国土交通省総合政策局：建設工事施工統計調査，19902013.

9）国土交通省総合制作局: 平成 24 年度建設見通し, 2013 .

10）中小企業庁: 官公需契約の手引き，1. 官公需施策の概要, 2011.

11) 小林潔司 : 建設プロジェクト契約におけるリスク分担, Civil Engineering Consultant, Vol.231，2006.

12) 小林潔司, 大本俊彦, 横松宗太, 若公崇敏: 建設請負契約 
の構造と社会効率性，土木学会論文集，No.688/IV-53, pp.89-100, 2001.

13) 大本俊彦，小林潔司，大西正光 : 建設契約における和解 と仲裁, 土木学会論文集, No.633/VI-53, pp.231-243, 2001.

14) 大本俊彦，小林潔司，若公崇敏: 建設請負契約におけるリ スク分担，土木学会論文集，No.633/VI-53，pp.205-217, 2001.

15）堀泰 : ゼネコンにおける協力会社関係の重要性一鹿島建設 とその協力会社の事例を中心として, 名城論叢, Vol.10, No.4, pp.187-207, 2010.

16) 財務省総合政策研究所 : 法人企業統計年次別調査, 20012012.

17）社団法人 日本土木工業協会 : 透明性ある入札・契約制度 に向けて-改革姿勢と提言,- 2006.

18） 草柳俊二 : 建設関連企業の国際展開について, 建設マネ ジメント技術，pp.7-12，2013.

19) 一般財団法人建設経済研究所 (RICE) : 専門工事業下請取 引実態調査, RICE (Research Institute of Construction and Economy) monthly 研究所だより一建設経済の最新 情報ファイル-, No.223，pp.15-23， 2007.

20）国土交通省 : 建設産業の再生と発展のための方策 2011, 2011.

21）大野泰資 : 公共工事における入札 ·契約方式の課題，会 計検査研究, No.27, pp.159-174, 2003.

22）貝戸清之, 青木一也, 小林潔司 : 実践的アセットマネジ メントと第 2 世代研究への展望，土木技術者実践論文集， Vol.1, pp.67-82, 2010.

23）国土交通省：設計・施工一括及び詳細設計付工事発注方 式実施マニュアル（案），2009.
24) 工藤匡貴, 宮武一郎, 馬場一人, 横井宏行, 笛田俊治: 設 計・施工一括発注方式の効果と適性に関する一考察，土 木学会論文集 F4（建設マネジメント）, Vol.67, No.4, pp.I_293-I_304, 2011.

25）岩崎郁夫, 太田誠, 酒井崇行, 長尾千瑛, 上東泰 : 新東 名高速道路青木川橋工事における設計・施工一括発注方 式適用に関する実践的研究, 土木学会論文集 F5（土木 技術者実践），Vol.68，No.2，pp.51-62， 2012.

26) 宮武一郎, 工藤匡貴, 馬場一人, 川俣裕行 : 設計 · 施工 一括発注方式のダム用選択取水設備工事への適用とその 効果についての一考察, 土木学会論文集 F4（建設マネ ジメント), Vol.68, No.4, pp.I_137-I_148, 2012.

27) 宮武一郎, 工藤匡貴, 川俣裕行, 笛田俊治: 設計・施工 一括発注方式におけるコンソーシアムの形態とその活用 についての一提案, 土木学会論文集 F4（建設マネジメ ント), Vol.67, No.4, pp.I_251-I_262, 2011.

28）閣議決定 : 公共工事の入札及び契約の適正化を図るため の措置に関する指針，2001。

29）国土交通省総合政策局：異業種 JV に係る調査報告書, 2005.

30) 天満知生，小澤一雅: 国土交通省直轄工事における設計施 工一括発注方式の現状と課題, 土木学会論文集 F4（建設 マネジメント), Vol.68, No.4, pp.I_115-I_124, 2012.

31）国土交通省土地・建設産業局 : 地域維持型建設共同企業 体の取扱いについて, 2011.

32）国土交通省土地・建設産業局:「地域維持型契約方式」の 導入について，建設マネジメント技術，pp.38-41， 2012.

(2015. 8. 12 受付)

\title{
ROLES AND SYSTEM DESIGN OF SPECIALIZED CONSTRUCTORS IN THE MAINTENANCE AND REPAIR OF INFRASTRUCTURE
}

\author{
Seiichi HAMADA, Eisaku SUGIHARA, Kiyoyuki KAITO and Daijiro MIZUTANI
}

\begin{abstract}
According to the Construction Industry Act, constructors are classified into comprehensive constructors and specialized constructors. In this study, the authors surveyed the actual situations regarding the increase in demand for the maintenance and repair of deteriorated social infrastructure, the number of orders for maintenance and repair and the contract amount received by constructors in each capital range, based on statistical data analysis, questionnaires, and interviews. Then, it was found that most of general maintenance and repair works are undertaken by specialized constructors with a capital of 10 to 50 million yen. The authors also mentioned that it is desirable that (1) specialized constructors take central roles in maintenance and repair works, according to the act on ensuring the receipt of orders from the government and other public agencies by small and medium-sized enterprise (SME), (2) with this, it is possible to reduce the incompleteness of maintenance and repair works, and (3) design and construction are ordered together. On the other hand, it was pointed out that specialized constructors are required to possess not only technical expertise, but also the ability to manage all construction processes.
\end{abstract}

